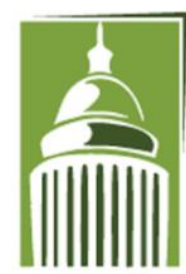

AR F
Global Proceedings Repository

American Research Foundation

ISSN 2476-017X
شبكة المور تمرات العر.ية

http://arab.kmshare.net/

Available online at http://proceedings.sriweb.org

The 10th International Scientific Conference

Under the Title

"Geophysical, Social, Human and Natural Challenges in a Changing Environment"

$$
\text { المؤتمر العلمي الدولي العاثر }
$$

تحت عنوان "التحديات الجيوفيزيائية والاجتماعية و الانسانية و الطبيعية في بيئة متغيرة"

$$
25 \text { - } 26 \text { يوليو - تموز } 2019 \text { - اسطنبول - تركيا }
$$

http://kmshare.net/isac2019/

$$
\text { استر اتيـيات تنمية الموارد البشرية و أثرها في تحسين اداء المنظمـات دراسـة تطبيقية على مصيرف الجمهورية الخمس }
$$

فتحية خليل اطحيشات

محاضربكلية الاقتصباد والتجارة الخمس

قسم إدارة الاعمال

fathiasha@gmail.com
أمين على بوحنيك

محاضربكلية الاقتصهاد والتجارة الخمس

قسم إدارة الاعمال

Aminbuhneik81@gmial.com

\title{
Abstract of the study
}

This post shows the achievement of human resources development strategies in the United States of America - English - Arabic - English - Arabic English language learning from the Institute of Graduate Studies (English) Institute of Graduate Studies (60) 


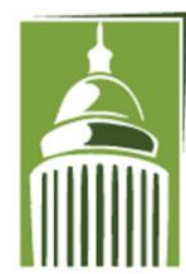

AR F
Global Proceedings Repository

American Research Foundation

ISSN 2476-017X

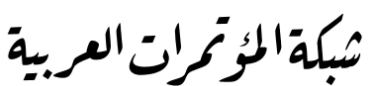

http://arab.kmshare.net/

Available online at http://proceedings.sriweb.org

employee at Ain Shams University (52) (37) only one, and this study reached several results, the most important of which:

1-There is a statistically significant effect of planning on the performance of banks, and the percentage of impact (13.7\%), unless it affects another effect

2-The existence of a significant effect of statistical significance for the selection and polarization on the performance of banks, and the percentage of impact (54.5\%) unless affected by another effect

3-There is a significant effect of statistical significance for training on the performance of banks, and the percentage of impact is (54.3\%) unless otherwise affected

4-There is a significant impact of statistical significance of the practice of human resources management on the performance of banks, and the impact rate $(66.5 \%)$ unless another impact

:The study also recommended the following points

1-Conduct training courses on an ongoing basis .

2-The need to attract the management of banks to human resources for those who have sufficient skills and experience in the functions of management control for the positions of management

3-The need for the management of banks to collect data and information about applicants for appointment for use in differentiation and appointment 


\section{Global Proceedings Repository}

American Research Foundation

ISSN 2476-017X
شبكة المؤمرات العربية

http://arab.kmshare.net/

Available online at http://proceedings.sriweb.org

4-The need to work within the banks with a clear organizational structure that defines the responsibilities and powers of all employees

Keywords ( Human Resources, Man Power Planning, Selection)

مستخلص الدراسـة

هدفت هذه الدراسة الى التعرف على أثر استراتيجيات تنمية الموارد البشرية ودورها في تحسين الاداء في مصرف الجمهورية الخمس وذلك من خلال التركيز على ذلك الاثر لممارسة الموارد البشرية من خلال التخطيط والاختيار والاستقطاب والتدريب على اداء تلك المصارف ، حيث تم استخدام المنهج الوصفي والتحليلي بوصفه المنهج الاكثر ملائمة لتلك الانواع من الدراسات ، تمثل مجتمع الدراسة من كافة العاملين بمصرف الجمهورية الخمس حيث بلغ مجتمع الدراسة (60) موظفا أما بالنسبة

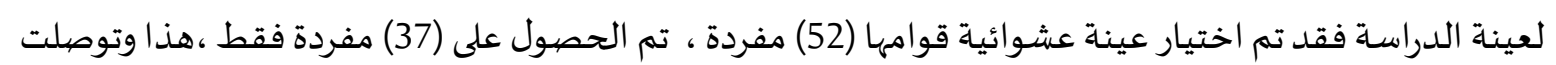
الدراسة الى عدة نتائج أهمها : - الهم

1. وجود أثر معنوي ذو دلالة إحصائية للتخطيط على أداء المصارف، وبلفت نسبة الأثر (13.7\%) ما لم يؤثر مؤثر آخر 2. وجود أثر معنوي ذو دلالة إحصائية للاختيار والاستقطاب على أداء المصارف، وبلغت نسبة الأثر (54.5\%) ما لم يؤثر مؤثر آخر

3. وجود أثر معنوي ذو دلالة إحصائية للتدريب على أداء المصارف ، وبلغت نسبة الأثر (54.3\%) ما لم يؤثر مؤثر آخر. 4.وجود أثر معنوي ذو دلالة إحصائية لممارسة إدارة الموارد البشرية على أداء المصارف ، وبلغت نسبة الأثر (66.5\%) ما لم يؤثر مؤثر آخر. كما أوصت الدراسة بجملة النقاط أهمها :1. العمل على إقامة الدورات التدريبية بصورة مستمرة من اجل تطوير عماليه والرفع من مستواهم. 2. ضرورة استقطاب إدارة المصارف للموارد البشرية للذين يمتلكون مهارات والخبرات الكافية في وظائف الإدارة

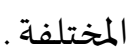

3. ضرورة اهتمام إدارة المصارف بجمع البيانات والمعلومات عن المتقدمين للتعيين لغرض استخدامها في المفاضلة والتعيين. 


\section{Global Proceedings Repository}

American Research Foundation

ISSN 2476-017X
شبكة المؤمرات العربية

http://arab.kmshare.net/

Available online at http://proceedings.sriweb.org

4. ضرورة العمل داخل المصارف بهيكل التنظيهي واضح يحدد مسؤوليات وصلاحيات بجميع الموظفين.

الكلمات المفتاحية : ( إدارة الموارد البشرية ، تخطيط القوى العاملة ، الاختيار، الاستقطاب ) .

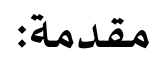

يعتبر المورد البشري أحد أهم مقومات نجاح أي منظمة وأهم عنصر من عناصر العمل والانتاج على الرغم من أن جميع تلك

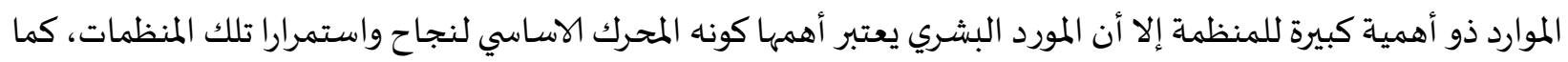

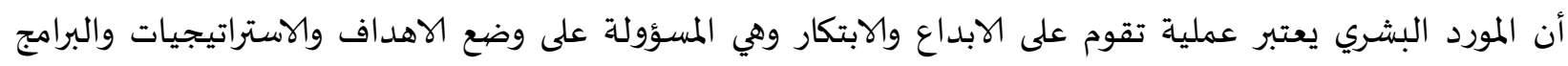

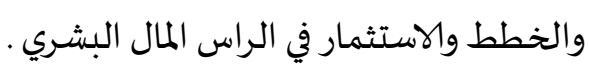
كما يعتبر المورد البشري هو اغلى وأثمن الموارد لدى المنظمات نظرا للدور الذي يلعبه في حياة تلك المنظمات من حيث الماري

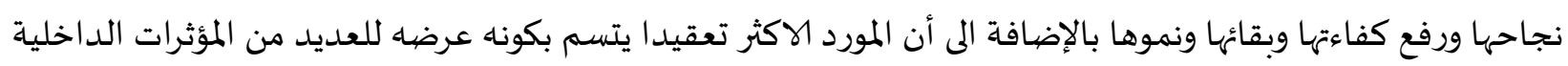
والخارجية .

فاذا كانت المنافسة هي المبدأ الذي تقوم عليها اقتصاديات اليوم ، فمما لاشك فيه فأن السعي لكسب الرهان أصبح أمرا

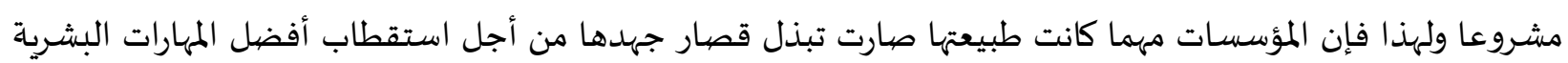

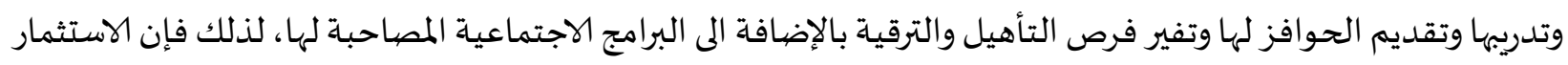

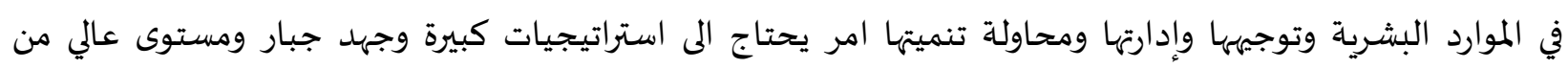
التخطيط طويل الامد. انطلاقا مما سبق فإن البحث سيحاول ابراز دور المورد البشري كاستراتيجية لتحسين اداء منظماتها في المصارف وذلك من

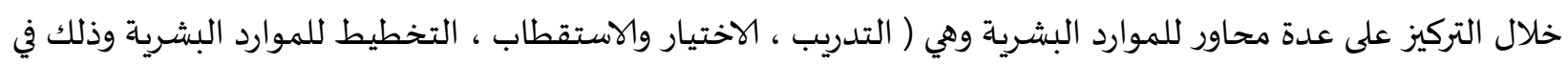
مصرف الجمهورية مدينة الخمس.

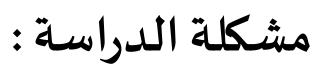

اصبحت تنمية الموارد البشرية ضرورة ملحة في المؤسسات المعاصرة نتيجة تزايد حجم ونوعية المنافسة المحلية والعالمية بين المؤسسات على اختلاف انواعها وذلك لتلبية حاجات ورغبات زبائها الحاليين والمتوقعين في المستقبل.

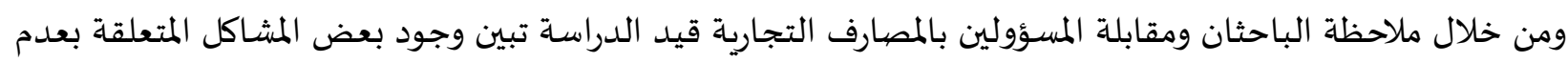

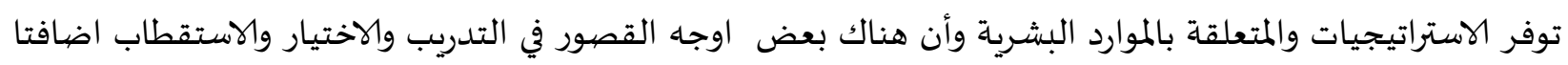

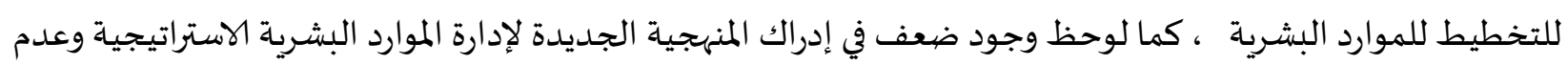
استيعاب مدلولاتها بالنسبة للعمل المصرفي ، ويمكن تشخيص مشكلة الدراسة بالتساؤل التالي:

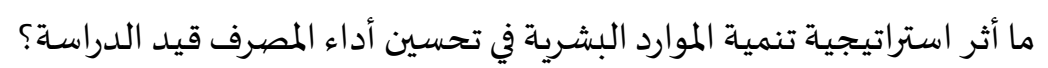




\section{Global Proceedings Repository \\ American Research Foundation}

\section{ISSN 2476-017X}

Available online at http://proceedings.sriweb.org
شبكة المؤرمَات العر.ية

http://arab.kmshare.net/

ARF

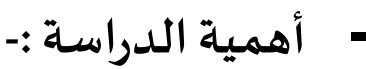

يقدم هذا البحث نتائج للمصارف التجارية في ليبيا عن أثر استراتيجيات تنمية الموارد البشرية في تحسين أداء

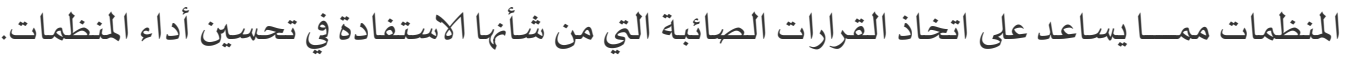

قد يفتح هذا البحث المجال لمزيد من البحوث والدراسات في مجال تنمية الموارد البشرية.

$$
\text { أهداف الدراسـة : ماف }
$$

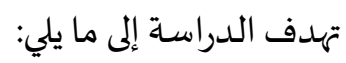

1- التعرف على أثر استراتيجيات تنمية الموارد البشرية المتبعة في المصارف التجارية قيد الدراسة في تحسين أداء

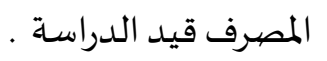

2- تقديم دليل علمي و مهني عن أهمية استراتيجية تنمية الموارد البشرية في تحسين الاداء المستدام في المصرف

$$
\text { قيد الدراسـة }
$$

3- تقديم بعض التوصيات والتي من شأهها أن تفيد المصارف التجارية بصفة عامة والمصرف قيد الدراسة

بالإضافة الى تقديم بعض التوصيات تفيد البحاث والكتاب كدراسات مستقبلية .

\section{منهج الدراسـة و أداة جمع البيانات:}

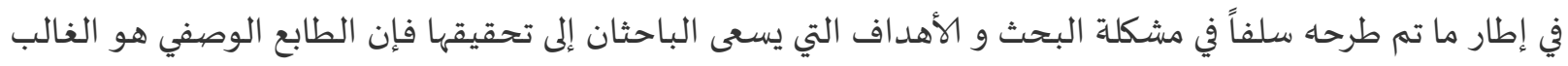

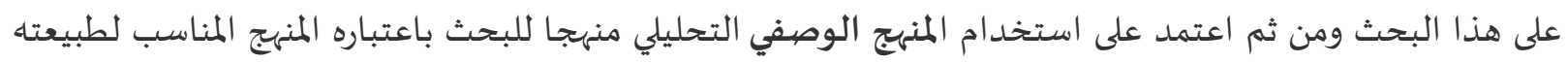

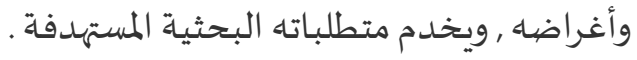
أما أداة جمع البيانات فسيتم اعتماد بشكل اساسي على أداة الاستبيان ، حيث سيتم إعداد استمارة استبيان من البنود

$$
\begin{array}{r}
\text { 3. } \\
\text { 3. }
\end{array}
$$

نتائج الدراسـة :

ستخضع البيانات المتحصل عليها للتحصيل الإحصائي باستخدام الرزمة الإحصيائية الجاهزة للعلوم الاجتماعية وصـــــولاً إلى النتائج ومن تم الخروج بالتوصيات و تقديم المقترحات. 


\section{Global Proceedings Repository \\ American Research Foundation}

\section{ISSN 2476-017X}

Available online at http://proceedings.sriweb.org
شبكة المؤرمَات العر.ية

http://arab.kmshare.net/

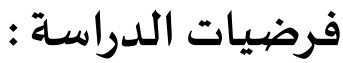

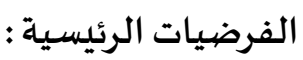

لاتوجد علاقة ذات دلالة إحصائية بين ممارسات إدارة الموارد البشرية وبين دورها في تحسين الاداء.

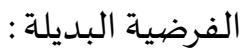

توجد علاقة ذات دلالة إحصائية بين ممارسات إدارة الموارد البشرية وبين دورها في تحسين الاداء.

وتتفرع منها الفرضيات الفرعية التالية : - (

- لا توجد علاقة ذات دلالة احصائية بين التدريب ودوره في تحسين الاداء.

- لا توجد علاقة ذات دلالة احصائية بين الاختيار والاستقطاب ودوره في تحسين الاداء.

- لا توجد علاقة ذات دلالة احصائية بين تخطيط الموارد البشرية ودوره في تحسين الاداء.

اهمية الدراسـة :

تكمن اهمية الدراسة في عدة نقاط اهمها :

1- النقلة النوعية الكبيرة التي يشهدها العالم اليوم و التي اصبحت لازما عليها تبني مسؤوليات جديدة ومبتكرة ممثلة في اكتساب مهارات ومعارف حديثة تساعدها على تحسين ادائها .

2- التحريات التي تواجه المؤسسات المصرفية في ليبيا بصفة عامة ومصرف الجمهورية والوحدة بصفة خاصة نتيجة للتغيرات السريعة والمستمرة في عدة مجالات علمية ومعرفية و التي فرضت نفسها كسبيل لتنمية مواردها البشرية . محاولة الدراسة في المساهمة في تحسين اداء عمل ادارة فروع الجمهورية والوحدة بتنمية مواردها البشرية وفق استراتيجية هادفة لتحسين ادائها.

\section{منهج الدراسـة :}

تستخلص الدراسة للأسلوب المنهج الوصفي في وصف الواقع الراهن للمصارف قيد الدراسة والمنهج التحليلي والذي يتمثل في تحليل البيانات التي يثم تجميعها والمعلومات من خلال استمارة الاستبيان . 


\section{Global Proceedings Repository \\ American Research Foundation}

\section{ISSN 2476-017X}

شبكة المؤرمُات العربية

http://arab.kmshare.net/

Available online at http://proceedings.sriweb.org

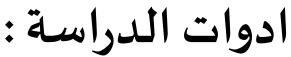

فيما يتعلق بالجانب النظري فقد تمت الاستعانة بما يتوفر للباحثين من كتب ودراسات سابقة ذات العلاقة بموضوع الدراسة للحصول على البيانات اللازمة بالخصوص اما الجانب التطبيقي فقد تم استخدام استمارة الاستبيان لجمع البيانات اللازمة وصولا للنتائج والتي على ضوئها تقدم التوصيات اللازمة .

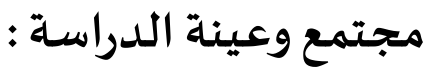

يتمثل مجتمع الدراسة في العاملين بمصرف الجمهورية ، والبالغ عددهم (60) موظف وتم أخذ عينة عشوائية قوامها (52) مفردة ، وتم الحصول على (37) مفردة فقط .

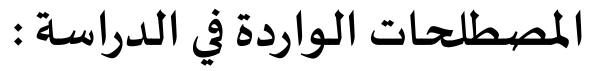

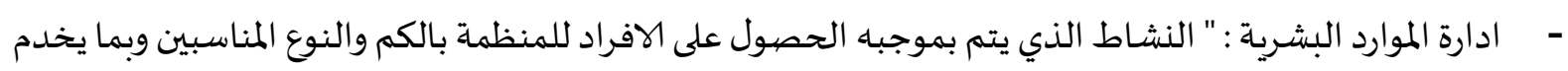

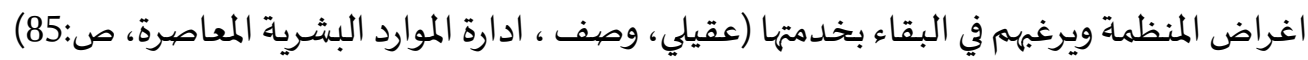

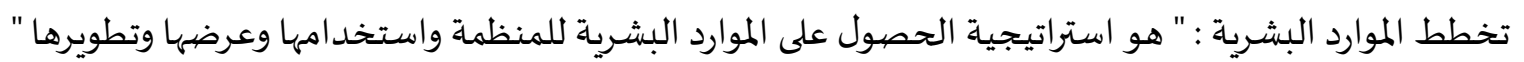

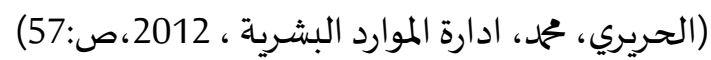
تخطيط القوى العاملة : "هو عملية الحصول على العدد الصحيح من الافراد المؤهلين للوظائف المناسبة في الوقت المناسب " n n

- اختيار والاستقطاب : الاختيار" هي عملية استنقاء الافراد اللذين لديهم المؤهلات الضرورية والمناسبة لشغل

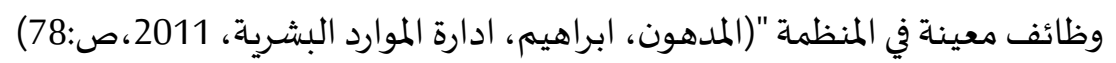
الاستقطاب : "هو ذلك النشاط الذي ينطوى على ايجاد اكبر عدد من المتقدمين المؤهلين ليتم الاختيار من بينهم

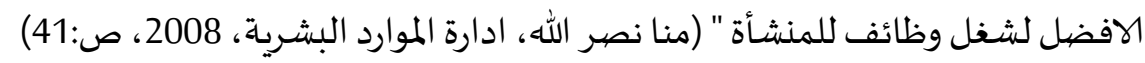

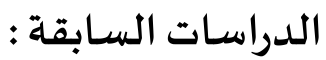
أ- دراسة طارق ابو عائشة (2011): رسالة ماجستير بعنوان : "التخطيط الاستر اتيجي و اثره على الاداء بالشركة

$$
\text { وهدتر اكية للمو اني " ،طر ابلس - ليبيا. }
$$

1- التعرف على والتحليل العلاقة بين التخطيط الاستراتيجي واداء الشركة قيد الدراسة . 2- التعرف على المعايير والاسس التي على اساسها يتم صياغة الاهداف الاستراتيجية وعلاقتها بالأداء بعينة

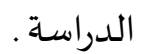
3- التعرف على مدى توفر متطلبات عملية التخطيط الاستراتيجي وعلاقتها بالأداء بعينة الدراسة . 


\section{Global Proceedings Repository}

American Research Foundation

ISSN 2476-017X
شبكة المؤمرات العربية

http://arab.kmshare.net/

Available online at http://proceedings.sriweb.org

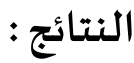

وهناك العديد من النتائج نذكر منها، الاتي :

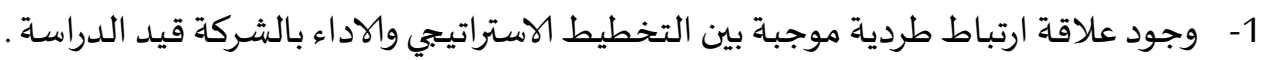

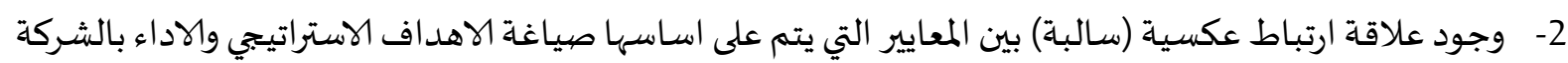

$$
\text { قيد الدراسة . }
$$

3- وجود علاقة ارتباط عكسية سالبة بين متطلبات التخطيط الاستراتيجي والاداء بالشركة قيد الدراسة .

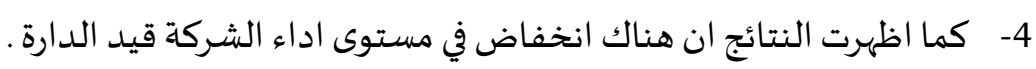

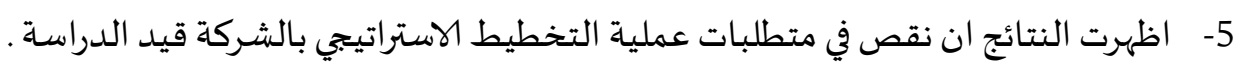

ب- إبراهيم ليلا (2013)و رسالة ماجستير بعنوان: تخطيط الموارد البشرية و أثره على فاعلية الأداء بالشركة الليبية للمو انئ.

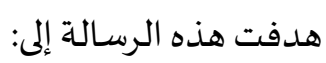

1- دراسة العلاقة بين تخطيط الموارد البشرية وفاعلية الأداء بالشركة قيد الدراسـة.

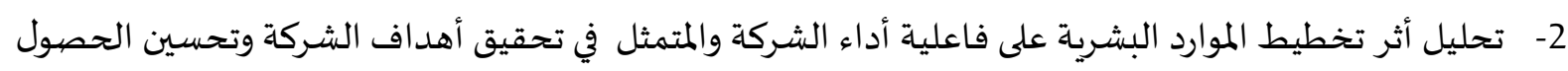

$$
\text { على الموارد البشرية. }
$$

3- التعرف على الأسس والأساليب المتبعة في إعداد وتنفذ خطة عمل الموارد البشرية وآلية عملها بالشركة محل

الدراسة.

4- معرفة مدى تطبيق الأساليب العملية في وصف وتوصيف الوظائف بالشركة قيد الدراسة.

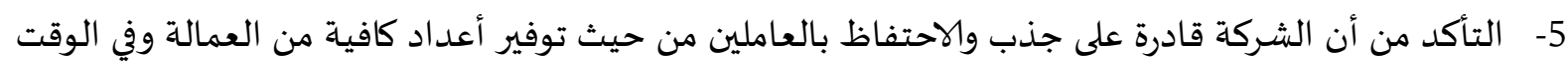

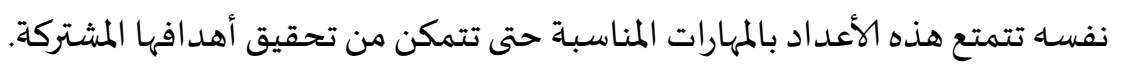

النتائج:

هناك العديد من النتائج نذكر منها الاتي:

1- التدني في استخدام السياسات الحاكمة للعمل وأساليب الإشراف وسلوكيات الرؤساء والعلاقات بينهم وبين

$$
\text { مرؤوسههم. }
$$

2- هناك أوجه خلل ملحوظة شملت تدني في التدريب والتنمية للكوادر البشرية من الداخل والمتخصصة في التعامل

$$
\text { مع المتغيرات التكنولوجياة. }
$$

3- القصور في تطبيق التشريعات والقوانين التي إعداد خطط الموارد البشرية.

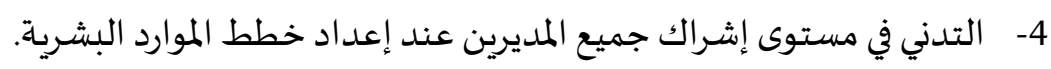

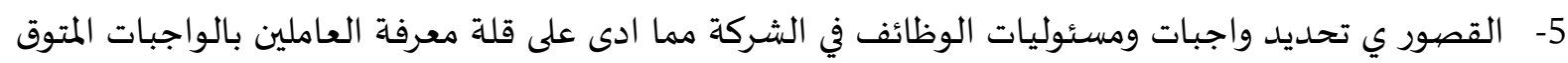

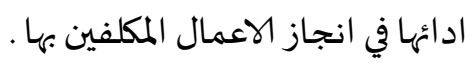




\section{Global Proceedings Repository}

American Research Foundation

ISSN 2476-017X

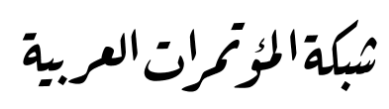

http://arab.kmshare.net/

Available online at http://proceedings.sriweb.org

6- ضعف في الاجور والمرتبات في الشركة محل الدراسة، مما ادى المى انخفاض مستوى اداء الموارد وتأثير ذلك على تدني فاعلية الاداء.

7- التذني في مستوى التوافق والانسجام بين اهداف الموارد البشرية من جهة واهداف الشركة من جهة اخرى .

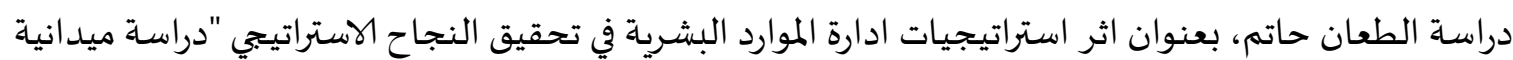

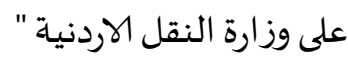
هدفت الدراسة الى الكشف عن نمط استراتيجيات ادارة الموارد البشرية والبحث اذا كانت عتبة الدراسة البها مؤهلة

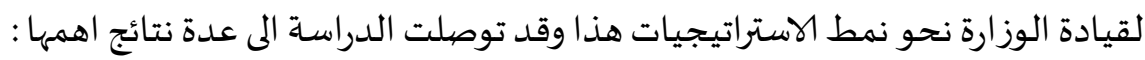

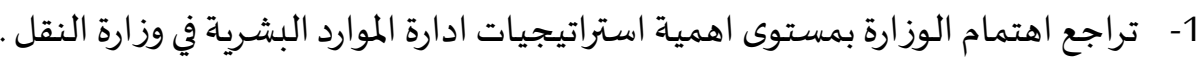

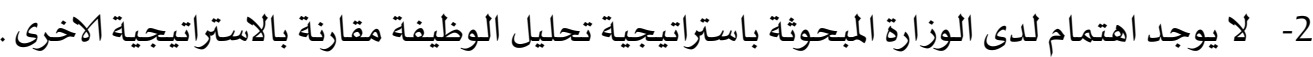

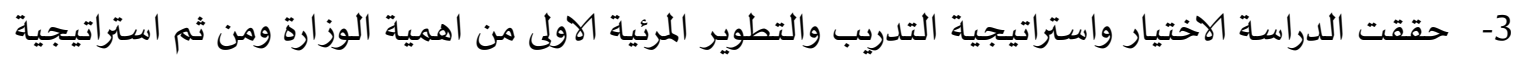

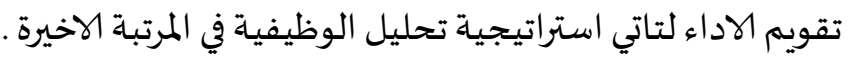

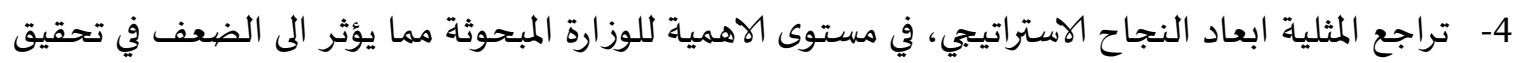
النجاح الاستراتيجي في وزارة النقل .

ج- استر اتيجية تنمية الموارد البشرية في المؤسسة الاقتصادية (حالة مؤسسة سوناطراك) ، أطروحة دكتور اه دولة في

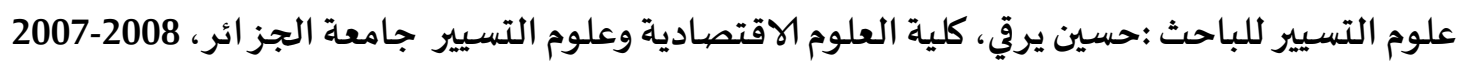

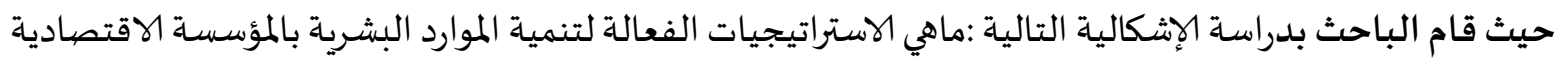

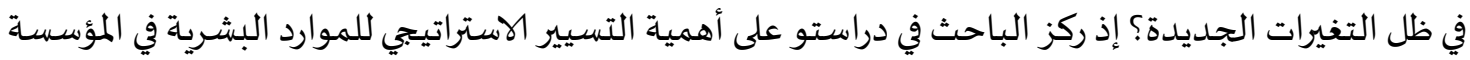
الاقتصادية وعلى أهمية الاستثمار في تنمية الموارد البشرية بالمؤسسة الاقتصاديادية، كذلك على الميلى كيفية التسيير الفعال

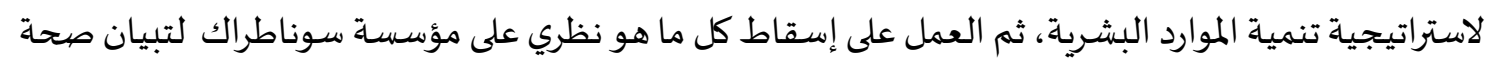

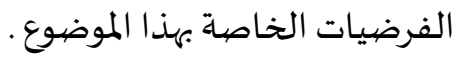

وقد توصلت هذه الدراسة إلى نتائج عديدة أهمها :أن تسيير الموارد البشرية يعد الآن من أهم أنظمة تسيير الموارد

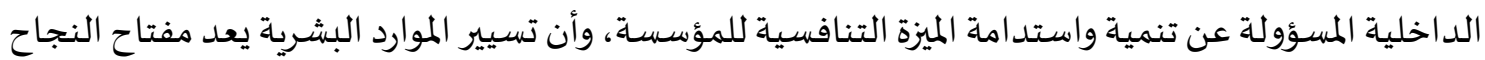

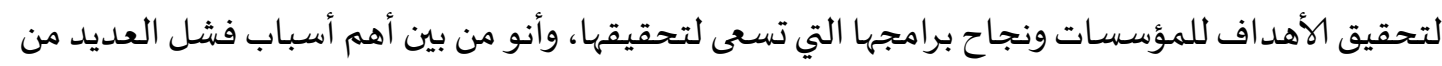

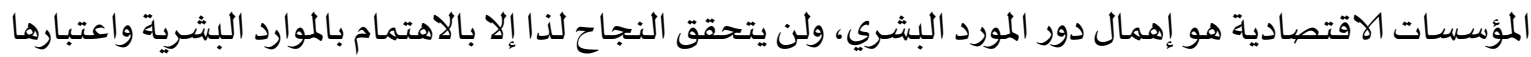
مدخلا لتحقيق الميزة التنافسية.

د.أثر التسيير الاستر اتيجي للموارد البشرية وتنمية الكفاءات على الميزة التنافسية للمؤسسة الاقتصادية مدخل

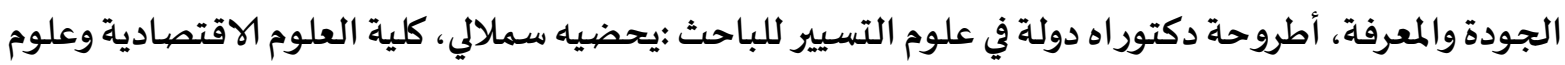
التسيير، جامعة الجز ائر،2003-2004 . 


\section{Global Proceedings Repository}

American Research Foundation

ISSN 2476-017X

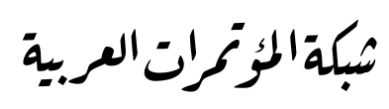

http://arab.kmshare.net/

Available online at http://proceedings.sriweb.org

حيث قام الباحث بدراسة الإشكالية التالية :هل يدكن للتسيير الاستراتيجي للموارد البشرية من خلال تسيير وتنمية

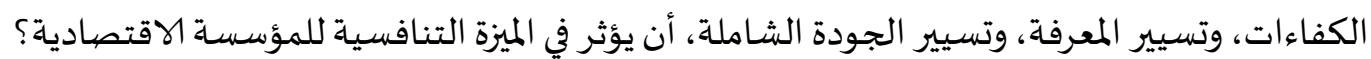

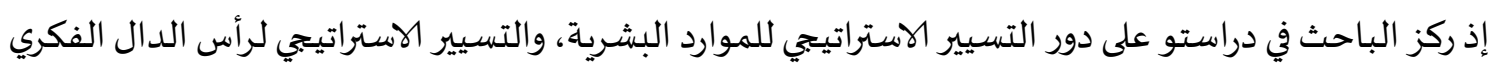

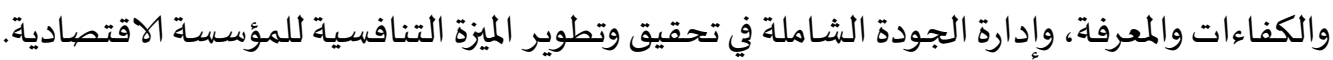

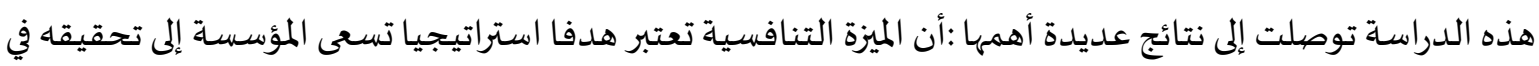

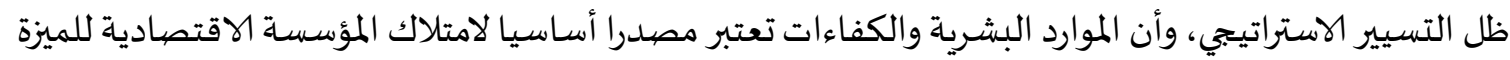

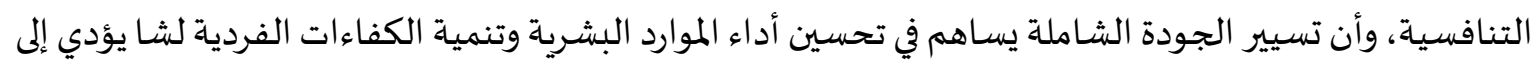
امتلاك المؤسسة للميزة التنافسية وهذا باعتباره مدخلا للتسيير الاستراتيجي للموارد البشرية.

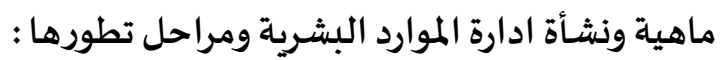

تعددت الراء والتسميات التي احاطت بنشاط القوى البشرية العاملة، وفي مجملها بقية منحازة في وصفيها

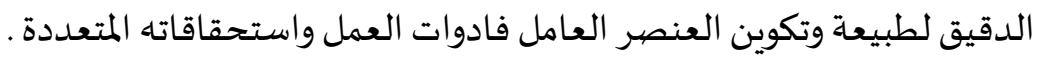

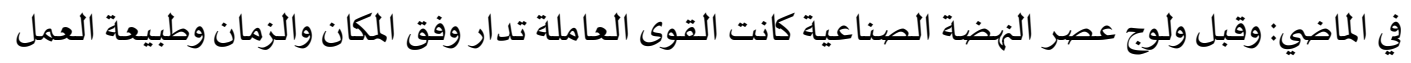

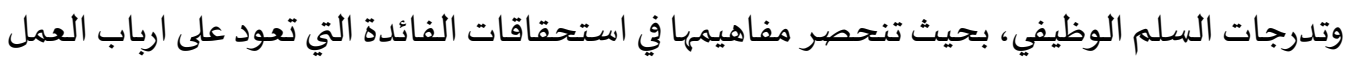

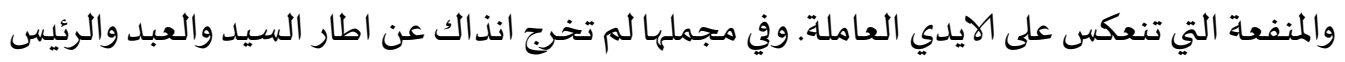

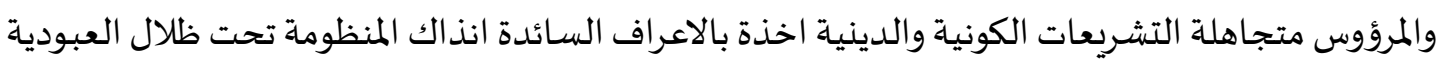

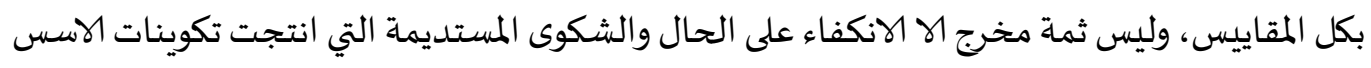

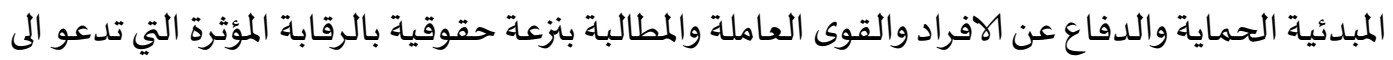
احترام حقوق الانسـان وفق التشريعات السماوية والمتطلبات الحقوقية للانسان والطبيعة البشرية، وعلية وعليها

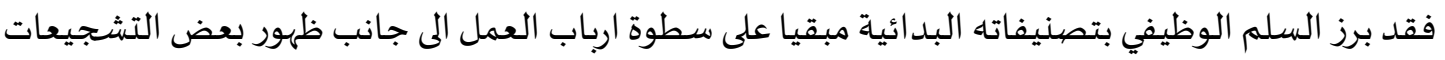
الوظيفية والمالية للقوى العاملة.

وصولا الى بداية تشكل (العنصر الصناعي) او (الثورة الصناعية) التي اشترطت مزيدا من التشريعات

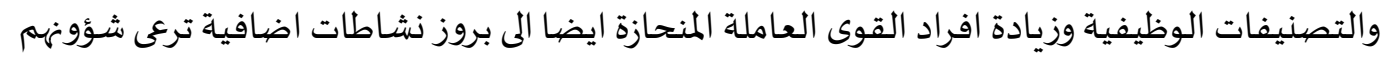

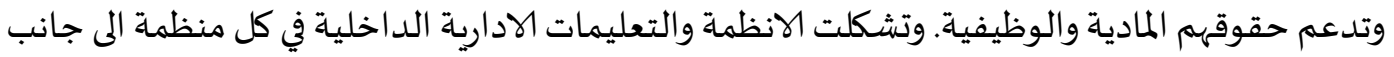
النصوص المتبعة لضمان سير العمل وفق الخطط الانتاجية.

وبذلك تطور مفهوم ادارة الموارد البشرية بتطوير ادوات العمل وتنوع انتاجها والتغيير في التركيبة المهارية والثقافية للموارد البشرية وزيادة الاخطار المتوقعة.

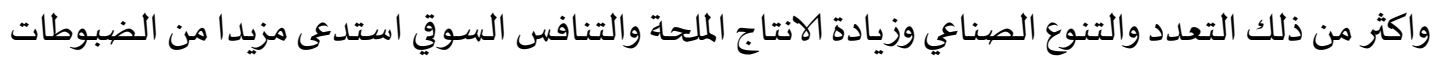

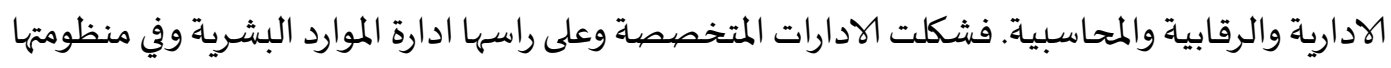

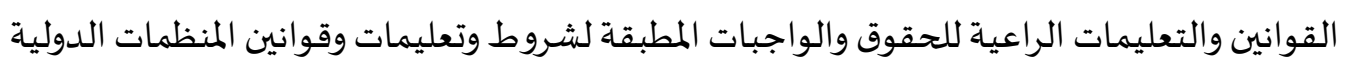

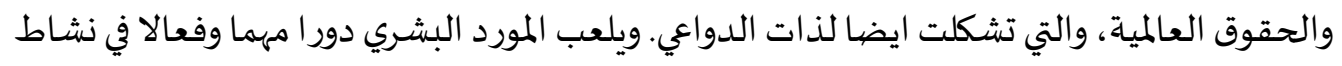
المنظمات وهو العنصر الفعال في التشغيل والانتاج. ومهما تعددت التسميات في نشاط القوى البشرية ال انها تلتقي في التطبيق والممارسة، ونجدي من التسميات: 


\section{Global Proceedings Repository}

American Research Foundation

ISSN 2476-017X

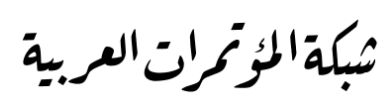

http://arab.kmshare.net/

Available online at http://proceedings.sriweb.org

$$
\text { - }
$$

وجميعها تنسجم في الممارسة، اذا تعني جميعها برفد المنظمات العاملة والمنشآت الصناعية وغير ذلك من

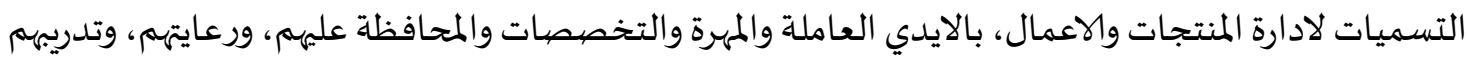

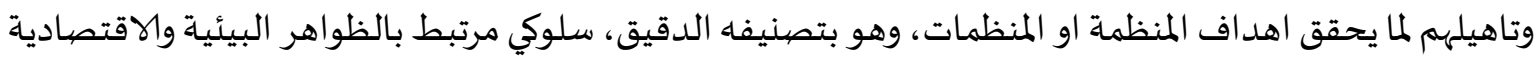

والاجتماعية وحتى السياسية.

وتعدد مسؤوليات ادارة الموارد البشرية وتتوسع انسجاما مع تطور وتوسع طبيعة وحجم العمل والانتاج.

ويدخل في اطارها الوظيفي المسؤوليات التالية :

1- الاهتمام بالفرد او الافراد ورعاية شؤونهم المادية والحقوقية المولية والسلوكية .

2- رفد المؤسسات والقطاعات الصناعية والانتاجية بالايدي العاملة والمهرة المتخصصية.

3- تعتبر حلقة وصل ما بين الفرد والمسؤول، والمؤسسات والدوائر والقطاعات الاخرى.

4- هي ادارة تنفيذية، من خلال ماتنجز من وظائف ادارية واستشارات.

5- صياغة استراتيجيات عمل للحصول على تلى موارد بشرية تلمتع بالكفاءات والقادرة على الابداع والابتكار

$$
\text { والتجديد. }
$$

6- ان ادارة الموارد البشرية تعتبر واحدة من اهم الوظائف لاي منظمة.

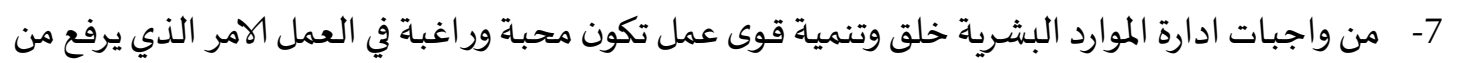

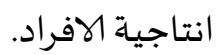

8- طرح وتقديم دراسـات التخطيط للموارد البشرية بمفهوم العملية الادارية، مثل تصميم الشواغر او السلم

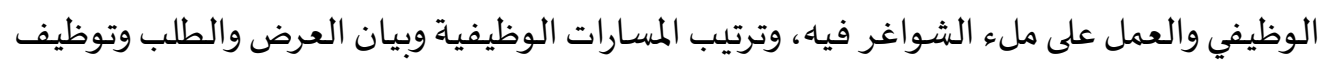

الاختصاصات التطبيقية.

ومن الواجبات الاساسية الملقاة على ادارة الموارد البشرية في أي منظمة تجاه الاهراد:

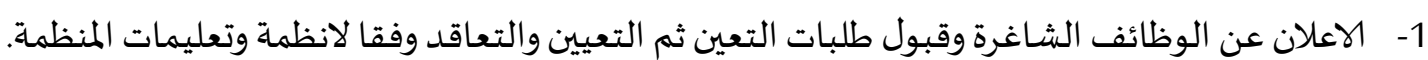

2- - الاحتفاظ بالسجلات والملفات الخاصة للعاملين . -

3- متابعة الشؤون الادارية والصحية الخاصة بالهات بالعاملين.

4- وضع تعليمات تنفيذ صرف مستحقات العاملين بالتنسيق مع الادارات المالية والحسابية.

5- لديها السلطة بمتابعة عمليات الترقية والاحالة والنقل بين العاملين.

6- دعم التعاون بين الاقسام والدارات المختلفة.

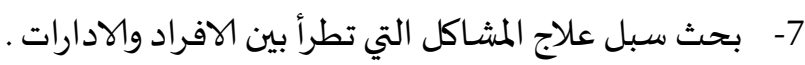

8- تقييم اداء الافراد ومتابعة ادائهم الوظيفي. 


\section{Global Proceedings Repository}

American Research Foundation

ISSN 2476-017X
شبكة المؤمرات العربية

http://arab.kmshare.net/

Available online at http://proceedings.sriweb.org

9- تحقيق الاهداف الفردية والتنظيمية

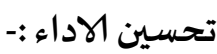

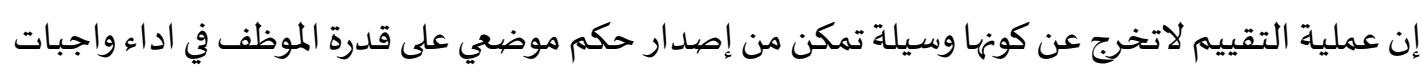

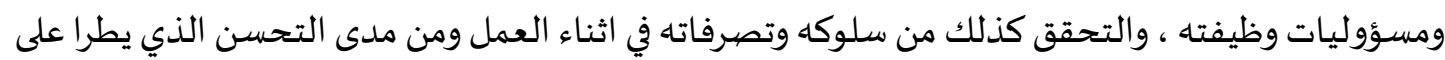

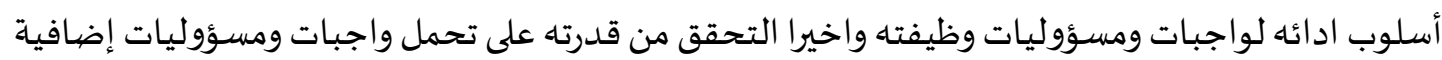

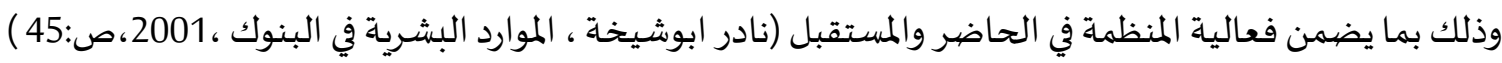

وتتبلور عملية التقييم في منظمات الاعمال لتصبح وظيفة متخصصية لها قواعدها وأصولها ويقوم بها متخصصيون

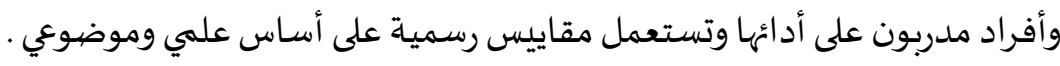

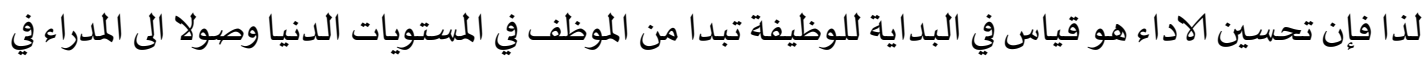

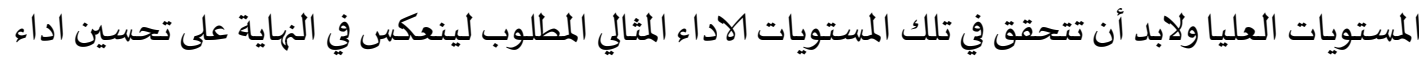

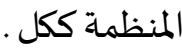

حدد جاري ديملر عدة طرق لتقييم الاداء وهي :-

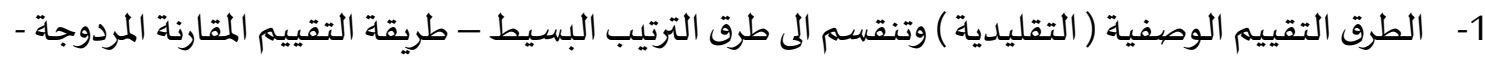

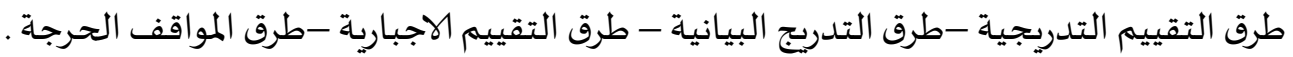
2- طرق التقييم الحديثة واتخذت عدة مقاييس ومنها مقياس التدرج السلوكي - مقياس الملاحظة السلوكية -

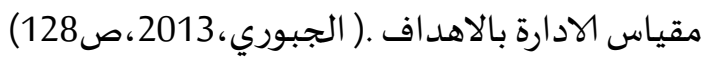

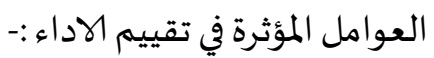

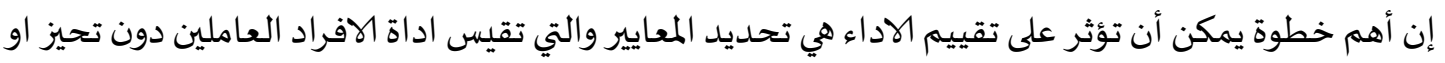

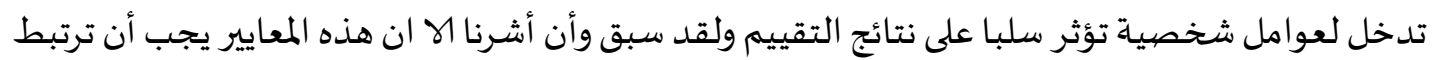
بالعمل الذي يؤديه الفرد ، الا أن هناك بعض الكائ الاخطاء في عملية التقييم ومن بين هذه الاخطاء مايلي:-

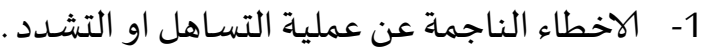

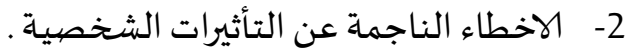
3- اخطاء التشابه. 4- اخطاء دافعية القيم. ( سهيلة وأخرون:271،2003) مقترحات لتطوير تقييم الاداء :1- استخدام المقاييس السلوكية بدلا من التركيز على الخصائص والصفات. 2- استخدام طرق متعددة فيوقت واحد لقياس اداء الافراد. 3- استمرارية التغذية العكسية لتعريفهم بمستوى ادائهم. 


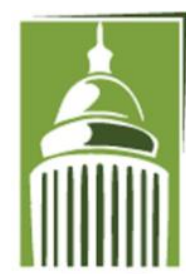

AR F
Global Proceedings Repository

American Research Foundation

ISSN 2476-017X
شبكة المؤمرات العربية

http://arab.kmshare.net/

Available online at http://proceedings.sriweb.org

$$
\begin{aligned}
& \text { 4- الاستعانة باكثر من مقيم. } \\
& \text { 5- ت تدريب وتهيئة المقيمين . }
\end{aligned}
$$

6- وضع نظام للمكافأة والجوافز لتشجيع العاملين.

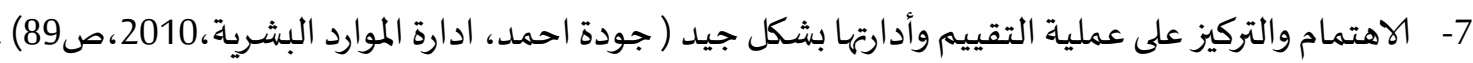

الخطوط العربضة لتطوير عملية التقييم :-

1- إجراء تحليل وظيفي لضبط المعايير والمقاييس المطلوبة لأداء وظيفي ناجح .

2- دمج هذه المعايير والمقايس في وسيلة تقييم مناسبة .

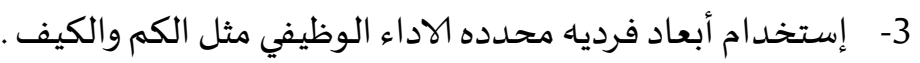

4- أخبار كل العاملين والقائمين بالتقييم بمعايير الاداء كتابيا .

5- عند إستخدام مقاييس التقييم البياني تجنب أسماء الخصائص المعنوية مثل ( الاخلاص والامانة ) .

6- إستخدام معدلات وتقييمات إشرافيه ( مثل المقالات) كأحد عناصر عملية إسية التقييم الشامل.

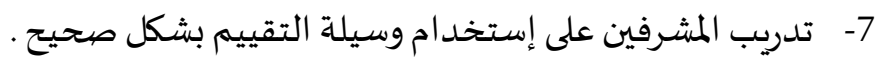

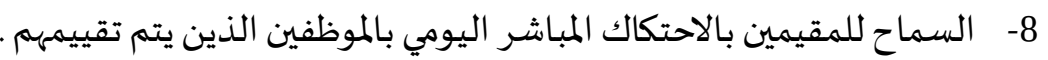

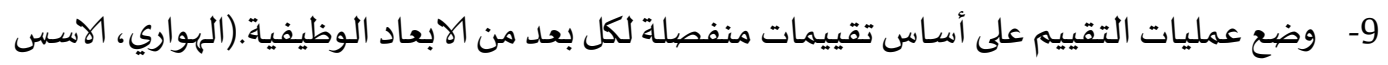

العلمية 2002، 111)

- مقدمة

يتناول هذا الفصل عرضياً مفصلاً للإجراءات التي تم الاعتماد عليها في تنفيذ الدراسة الميدانية بهدف التعرف على أثر ممارسات إدارة الموارد البشرية في تحسين الأداء المنظمات، ويشمل هذا الفصل أداة جمع البيانات وطرق إعدادها والأساليب المستخدمة في التحليل الإحصائي إضافة إلى صدق أداة الدراسة وثباتها وكذلك مجتمع وعينة الدراسة.

- - - أداة الدراسة

استخدم الباحثان الاستبيان لغرض تحقيق أهداف الدراسة فقامو بتصميم استمارة الاستبيان، واشتملت على

جزأين أساسيين حيث أستخدم الجزء الأول في جمع البيانات الشخصية عن المبحوثين والمتمثلة بالجنس، العمر، المستوى التعليمي، سنوات الخبرة والوظيفة الحالية، أما الجزء الثاني من الاستمارة فتكون من مجموعة من المحاور الخاصة

$$
\text { أولاً: المتغير المستقل: ممارسات إدارة الموارد البشرية }
$$




\section{Global Proceedings Repository}

American Research Foundation

\section{ISSN 2476-017X}

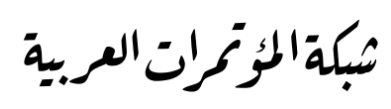

http://arab.kmshare.net/

Available online at http://proceedings.sriweb.org

$$
\begin{array}{r}
\text { 2. } \\
\text { 3. (التحتيار والاستقطاب) وتكون المحور من (6) فقرات. وتكون المحور من (6) فقرات. }
\end{array}
$$

ثانياً: المتغير التابع

التقييم والأداء: وتكون المحور من (10) فقرات

$$
\text { وتكون إجمالي الاستبيان من (29) فقرة، ما عدا البيانات الشخصية. }
$$

وقد استخدم الباحثان الترميز الرقمي في ترميز إجابات أفراد المجتمع للإجابات المتعلقة بالمقياس الخماسي، حيث تم إعطاء درجة واحدة للإجابة (غير موافق بشـدة) ودرجتان للإجابة (غير موافق) وثلاث درجات للإجابة (محايد) وأربع درجات

للإجابة (موافق) وخمس درجات للإجابة (موافق بشدة)، وقد تم استخدام متوسط القياس (3) وهو متوسط القيم (1 ، 2 ،

\begin{tabular}{|c|c|c|c|c|c|}
\hline موافق بشـدة & موافق & محايد & غير موافق & غير موافق بشـدة & الإجابة \\
\hline 5 & 4 & 3 & 2 & 1 & الترميز \\
\hline
\end{tabular}
3 ، 4 ، 5) للإجابات الخمسـة، كنقطة مقارنة لتحديد مستوى إجمالي كل محور من محاور الدراسة.

جدول (1) ترميز بدائل الإجابة وطول خلايا المقياس

\begin{tabular}{|c|c|c|c|c|c|}
\hline موافق بشـدة & موافق & محايد & غير موافق & غير موافق بشـدة & الإجابة \\
\hline $5-4.2$ & $4.19-3.4$ & $3.39-2.6$ & $2.59-1.8$ & $1.79-1$ & المتوسط المرجح \\
\hline
\end{tabular}

وكان طول الفترة المستخدمة هي 0.8 وقد تم حساب طول الفترة على أسـاس قسمة 4 على 5.

جدول (2) يبين طول خلايا المقياس

الأساليب الإحصائية المستخدمة

لقد تم إدخال البيانات إلى الحاسب الآلي بعد ترميزها؛ لإجراء العمليات الإحصائية اللازمة لتحليل البيانات باستخدام البرنامج الإحصائي، الحزم الإحصائية للعلوم الاجتماعية(1) وذلك للإجابة على تساؤلات الدراسة أو التحقق من 


\section{Global Proceedings Repository}

American Research Foundation

ISSN 2476-017X
شبكة المؤمرات العربية

http://arab.kmshare.net/

Available online at http://proceedings.sriweb.org

فرضياتها بمستوى معنوية (0.05) والذي يُعَد مستوى مقبولاً في العلوم الاجتماعية والإنسانية بصورة عامة(2)، وبما أننا نحتاج في بعض الأحيان إلى حساب بعض المؤشرات التي يمكن الاعتماد عليها في وصف الظاهرة من حيث القيمة التي تتوسط القيم أو تنزع إلهها القيم، ومن حيث التعرف على مدى تجانس القيم التي يأخذها المتغير، وأيضا ما إذا كان هناك قيم شاذة

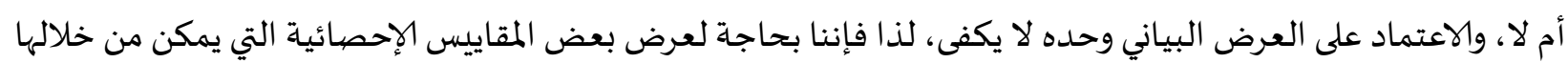
التعرف على خصائص الظاهرة محل البحث، وكذلك إمكانية مقارنة ظاهرتين أو أكثر، ومن أهم هذه المقاييس، مقاييس

$$
\text { النزعة المركزية والتشتت. وقد تم استخدام الآتي: }
$$

التوزيعات التكرارية: لتحديد عدد التكرارات، والنسبة المئوية للتكرار التي تتحصل عليه كل إجابة، منسوبا إلى إجمالي التكرارات، وذلك لتحديد الأهمية النسبية لكل إجابة ويعطي صورة أولية عن إجابة أفراد مجتمع الدراسة

$$
\text { على العبارات المختلفة. }
$$

• المتوسط الحسابي: يستعمل لتحديد درجة تمركز إجابات المبحوثين عن كل فقرة ، حول درجات المقياس، وذلك

$$
\text { لتحديد مستوى كل محور من محاور الدراسة. }
$$

• المتوسط الحسابي المرجح، لتحديد اتجاه الإجابة لكل عبارة من عبارات المقياس وفق مقياس التدرج الخماسي. • الانحراف المعياري: يستخدم الانحراف المعياري لقياس تشتت الإجابات ومدى انحرافها عن متوسطها الحسابي. • اختبار تي ( test): لتحديد جوهرية الفروق بين متوسط الاستجابة ومتوسط القياس (3) في المقياس الخماسي. معامل الارتباط : لتحديد العلاقة بين كل محور وإجمالي الاستبيان.

$$
\text { صدق فقرات الاستبانة }
$$

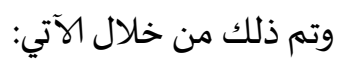

صدق المحكمين

يعد الصيدق من الشروط الضرورية واللازمة لبناء الاختبارات والمقاييس والصدق يدل على مدى قياس الفقرات للظاهرة المراد قياسها، وان أفضل طريقة لقياس الصدق هو الصدق الظاهري والذي هو عرض فقرات المقياس على

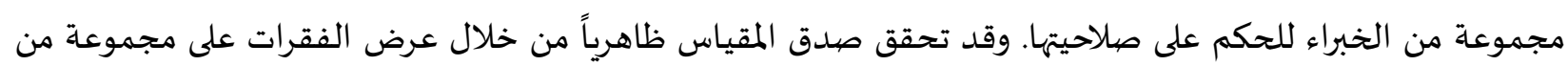

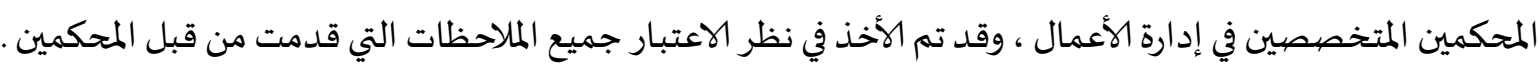

$$
\text { صددق الاتساق البنائي لمحاور الدراسـة. }
$$

$\left(^{2}\right)$ Uma Sekaran : Research Methods For Business, A Skill - Building Approach, Fourth Edition, Southern Illinois University at Carboundale, 2003, p24. 


\section{Global Proceedings Repository}

American Research Foundation

ISSN 2476-017X

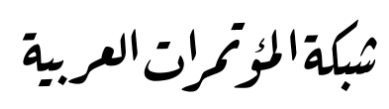

http://arab.kmshare.net/

Available online at http://proceedings.sriweb.org

جدول (3) معامل الارتباط بين محاور الدراسة وإجمالي الاستبيان

\begin{tabular}{|c|c|c|c|c|}
\hline قيمة الدلالة الإحصائية & معامل الارتباط & عدد الفقرات & المحـــاور & ت \\
\hline 0.000 & 0.657 & 7 & التخطيط & 1 \\
\hline 0.000 & 0.869 & 6 & الاختيار والاستقطاب & 2 \\
\hline 0.000 & 0.859 & 6 & التدريب & 3 \\
\hline 0.000 & 0.9 & 10 & التقييم والأداء & 4 \\
\hline
\end{tabular}

لقد بينت النتائج في الجدول (4) أن قيمة معامل الارتباط بين إجمالي الاستبيان ومحور (التخطيط) تساوي (0.657)، وبين إجمالي الاستبيان ومحور (الاختيار والاستقطاب) تساوي (0.869)، وبين إجمالي الاتبيان ومحور(التدريب) تساوي (0.859)، وبين إجمالي الاستبيان ومحور(التقييم والأداء) تساوي (0.9)، وكانت قيم الدلالة الإحصيائية دالة إحصيائياً عند مستوى المعنوية 0.05 حيث كانت قيم الدلالة الإحصائية جميعها أقل من 0.05 .

وهو الاتساق في نتائج المقياس إذ يعطي النتائج نفسها بعد تطبيقه مرتين في زمنين مختلفين على الإفراد نفسهم، وتم حساب الثبات عن طريق معامل ألفا كرونباخ حيث إن معامل ألفا يزودنا بتقدير جيد في أغلب المواقف وتعتمد هذه

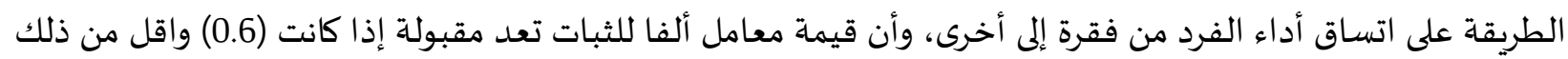
تكون منخفضة(3)، ولاستخراج الثبات وفق هذه الطريقة تم استخدام استمارات البالغ عددها (37) استمارة، وقد كانت قيمة معامل ألفا لثبات المحور "التخطيط" (0.824) ولمحور "الختيار والاستقطاب" (0.885) ولمحور "التدريب" (0.855)، ولمحور "التقييم والأداء" (0.915) وبلغ معامل الثبات لإجمالي الاستبيان بهذه الطريقة (0.944)، وبالتالي يمكن القول أنها معاملات ذات دلالة جيدة لأغراض البحث ويمكن الاعتماد عليها في تعميم النتائج.

( ${ }^{3}$ Uma Sekaran : Research Methods For Business, A Skill - Building Approach, Fourth Edition, Southern Illinois University at Carboundale, 2003, p311 


\section{Global Proceedings Repository}

American Research Foundation

\section{ISSN 2476-017X}

شبكة المؤمرات العربية

http://arab.kmshare.net/

Available online at http://proceedings.sriweb.org

الجدول (4) معامل الفاكرونباخ للثبات

\begin{tabular}{|c|c|c|c|}
\hline معامل ألفا & عدد الفقرات & المحـــور & ت \\
\hline 0.824 & 7 & التخطيط & 1 \\
\hline 0.885 & 6 & الاختيار والاتقطاب & 2 \\
\hline 0.855 & 6 & التدريب & 3 \\
\hline 0.915 & 10 & التقييم والأداء & 4 \\
\hline 0.944 & 29 & إجمالي الاستبانة & \\
\hline
\end{tabular}

مجتمع الدراسة

يتكون مجتمع الدراسة من العاملين بمصرف الجمهورية فرع الخمس والبالغ عددهم ( 60 ) موظف، وقد تم اعتماد

أسلوب المعاينة فاعتمد الباحثان عينة عشوائية احتمالية قوامها (52) مفردة، استمارة أستردو منها (37) استمارة صالحة للتحليل مبين بالجدول أدناه.

جدول رقم (5) الاستمارات الموزعة والمتحصل عليها ونسبة المسترد والفاقد منها

\begin{tabular}{|c|c|c|c|c|c|c|}
\hline نسبة & عدد & نسبة & عدد & نسبة & عدد & عدد \\
\hline الاستمارات & الاستمارات & الاستمارات & الاستمارات & الاستمارات & الاستمارات & الاستمارات \\
\hline الصالحة & الصالحة & الغير صالحة & غير صالحة & المفقودة & المفقودة & الموزعة \\
\hline \%71.15 & 37 & $\% 0$ & 0 & $\% 28.85$ & 15 & 52 \\
\hline
\end{tabular}

الوصف الإحصائي لمجتمع الدراسـة وفق الخصائص والسمات الشخصيـة

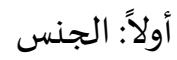

جدول رقم (6) يوضح توزيع أفراد العينة حسب الجنس 


\section{Global Proceedings Repository}

American Research Foundation

\section{ISSN 2476-017X}

ثبكةالمزّمراتيالربية

http://arab.kmshare.net/

Available online at http://proceedings.sriweb.org

\begin{tabular}{|c|c|c|}
\hline \% الجنس & ذكرار(ك) \\
\hline 94.6 & 35 & أنثى \\
\hline 5.4 & 37 & \\
\hline 100 & 37 & \\
\hline
\end{tabular}

بينت النتائج في جدول(6) أن غالبية أفراد العينة وما نسبته (94.6\%) كانوا من الذكور في حين أن مبحوثين اثنان وما نسبته (5.4\%) من الإناث.

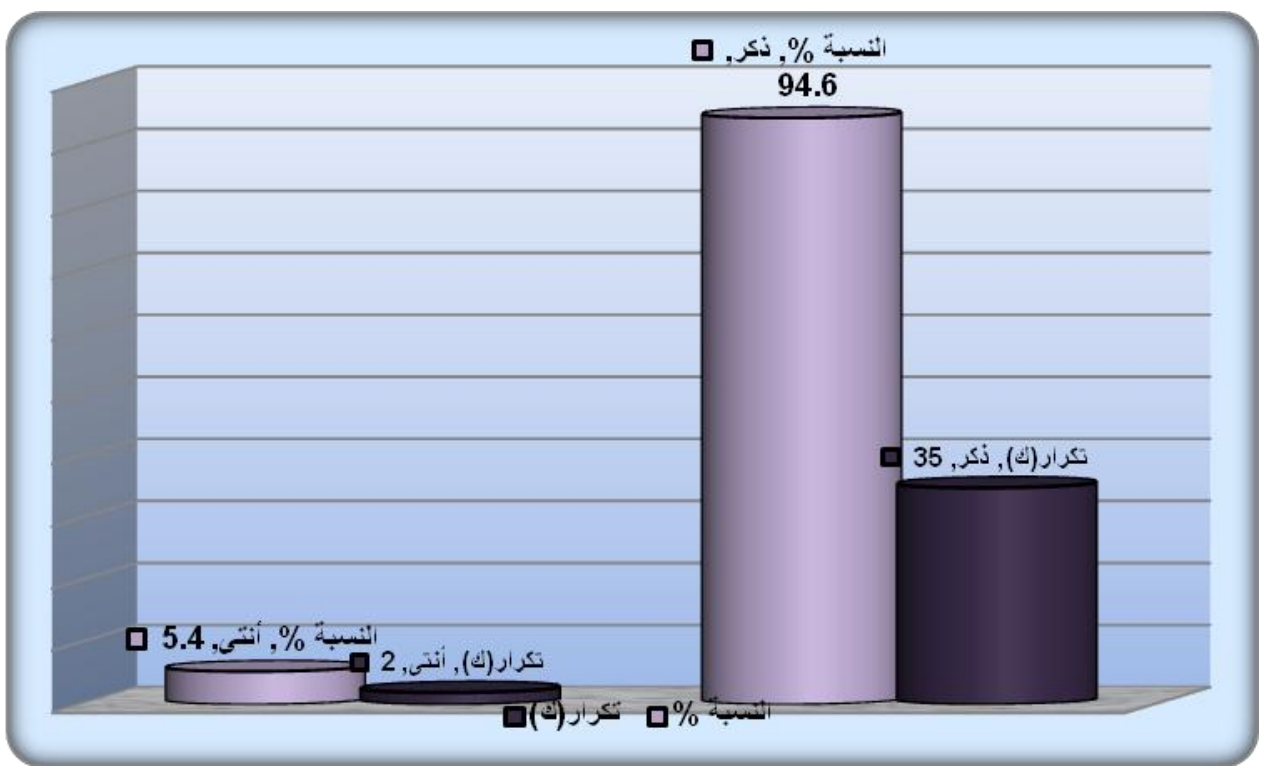

شكل رقم (1) يوضح توزيع أفراد العينة حسب الجنس.

ثانياً: العمر

جدول رقم (7) يوضح توزيع أفراد العينة حسب العمر

\begin{tabular}{|c|c|c|}
\hline النسبة\% & التكرار(ك) & العمر \\
\hline 32.4 & 12 & من30 إلى 35 \\
\hline
\end{tabular}




\section{Global Proceedings Repository}

American Research Foundation

\section{ISSN 2476-017X}

ثبكةالمزّمراتيالربية

http://arab.kmshare.net/

Available online at http://proceedings.sriweb.org

\begin{tabular}{|r|r|r|}
\hline 56.8 & 21 & 45 من \\
\hline 10.8 & 4 & 55 من 45 \\
\hline 100.0 & 37 & إلمجموع \\
\hline
\end{tabular}

بينت النتائج في جدول (7) أن غالبية أفراد العينة وما نسبته (56.8\%) تراوحت أعمارهم بين 35 إلى 45 في حين أن (12)

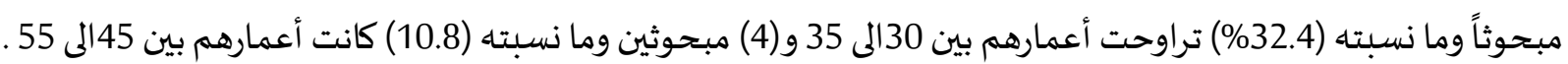

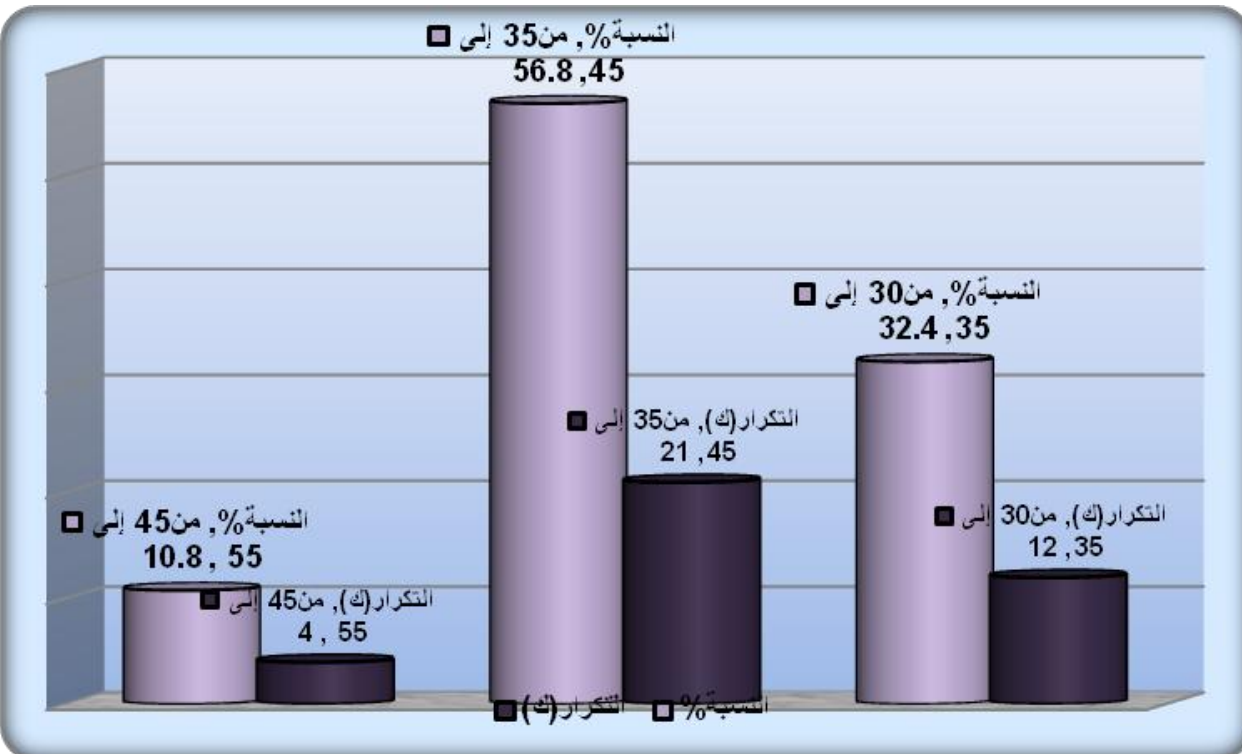

شكل رقم (2) يوضح توزيع أفراد العينة حسب العمر

ثالثًا: المستوى التعليهي

جدول رقم (8) يوضح توزيع أفراد العينة حسب المستوى التعليمي

\begin{tabular}{|c|c|c|}
\hline النسبة\%\% & التكرار(ك) & المستوى التعليمي \\
\hline 2.7 & 1 & إعدادي \\
\hline 13.5 & 5 & دبلوم متوسط \\
\hline 13.5 & 5 & عالي دبلوم \\
\hline 54.1 & 20 & بكالوريوس \\
\hline 10.8 & 4 & ماجستير \\
\hline 5.4 & 2 & دكتوراه \\
\hline 100.0 & 37 & المجموع \\
\hline
\end{tabular}




\section{Global Proceedings Repository}

American Research Foundation

\section{ISSN 2476-017X}

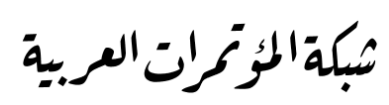

http://arab.kmshare.net/

Available online at http://proceedings.sriweb.org

بينت النتائج في جدول(8) أن مبحوثاً واحداً وما نسبته (2.7\%) كان خريج الإعدادية و(5) مبحوثاً وما نسبته (13.5\%) من

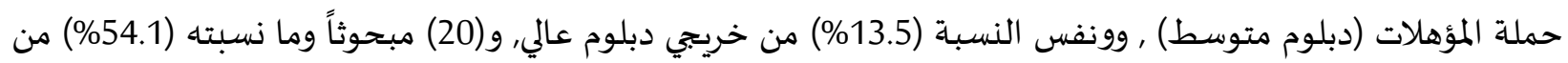
حملة المؤهلات الجامعية (البكالوريوس), و(4) مبحوثين وما نسبته (10.8\%) من حملة المؤهلات العليا (الماجستير) ومبحوثان اثنان وما نسبته (5.4\%) من حملة المؤهلات الدقيقة (دكتوراه).

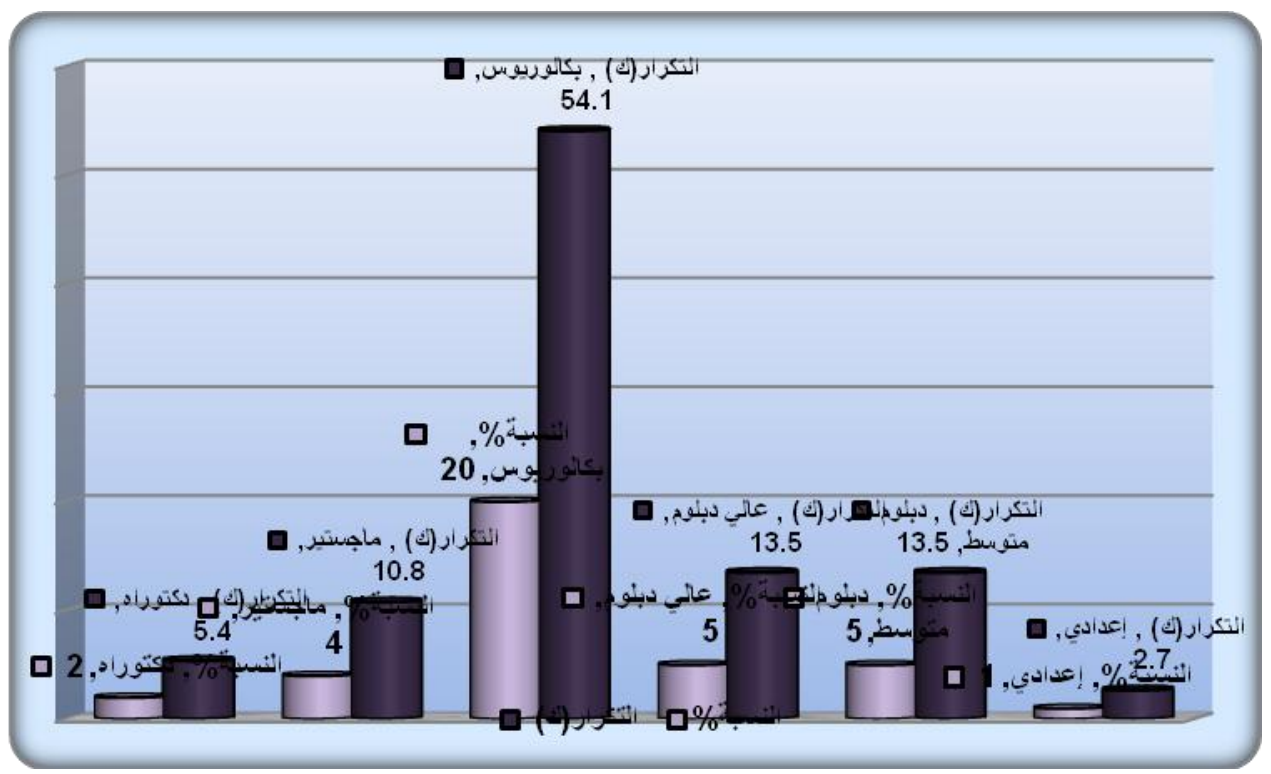

شكل رقم (3) يوضح توزيع أفراد العينة حسب المستوى التعليمي

رابعا: عدد سنوات الخبرة

جدول رقم (9) يوضح توزيع أفراد العينة حسب سنوات الخبرة

\begin{tabular}{|c|c|c|}
\hline النسبة & التكرار & سنوات الخبرة \\
\hline 16.2 & 6 & أقل من 5 سنوات \\
\hline 27.0 & 10 & 5إلى اقل من 10 سنوات \\
\hline 24.3 & 9 & 10إلى اقل من 15 سنة \\
\hline 32.4 & 12 & 15سنة فأكثر \\
\hline 100.0 & 37 & المجموع \\
\hline
\end{tabular}

بينت النتائج في جدول(10) أن (6) مبحوثين وما نسبته (16.2\%) كانت لهم خبرة أقل من 5 سنوات و (10) مبحوثاً وما نسبته (27\%) تراوحت خبتههم بين 5 إلى أقل من10 سنوات , و(9) مبحوثين وما نسبته (24.3\%) تراوحت خبتههم بين 10 إلى أقل من 15 سنة , و (12) مبحوثاً وما نسبته (32.4\%) كانت خبرتهم 15 سنة فأكثر. 


\section{Global Proceedings Repository}

American Research Foundation

\section{ISSN 2476-017X}

Available online at http://proceedings.sriweb.org

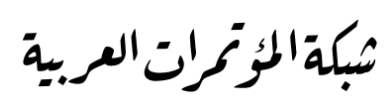

http://arab.kmshare.net/

AR F

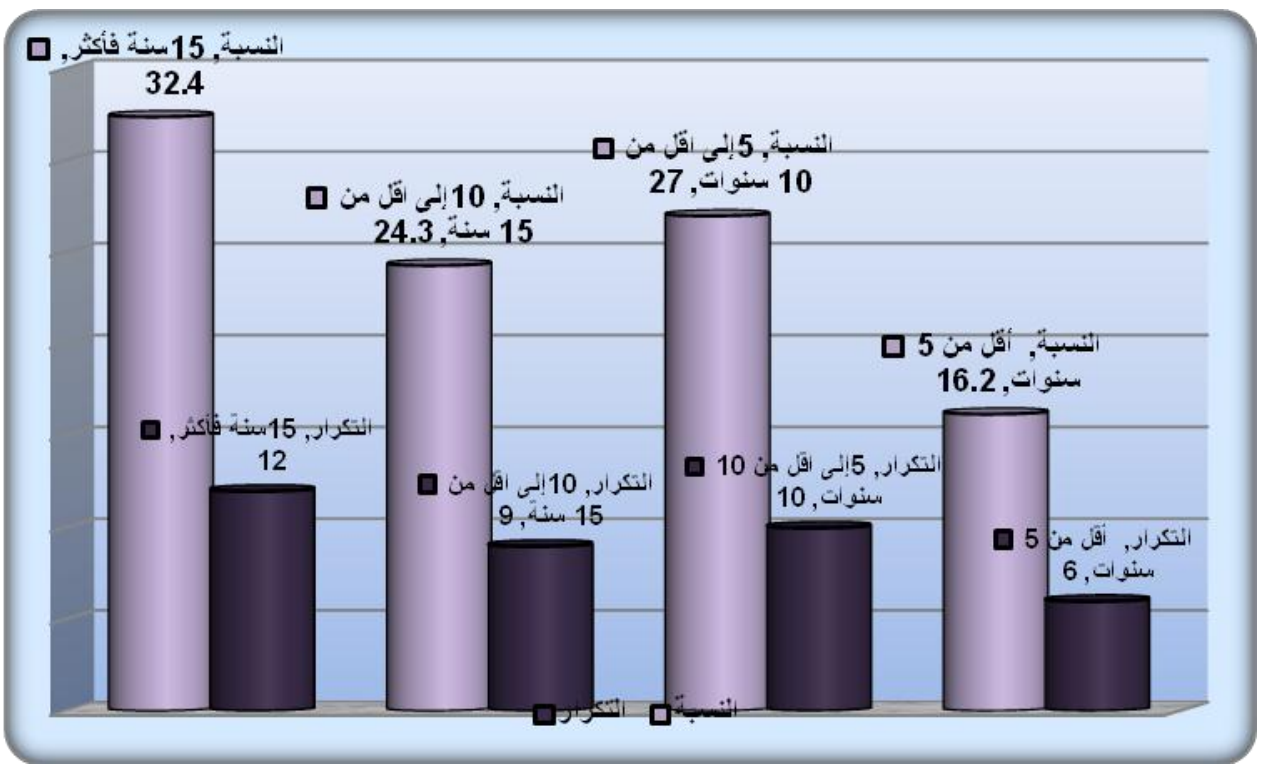

شكل رقم (4) يوضح توزيع أفراد العينة حسب سنوات الخبرة

وبذلك فإن البيانات الشخصية تعتبر مؤشرات إيجابية تساعد في وصول الدراسة الحالية إلى حقائق علمية يمكن تعميمها على مجتمع الدراسة لما فيها من تنوع في الجنس والعمر والمؤهلات العلمية والمسمى الوظيفي. الوصف الإحصائي لمحاور الدراسة وفق إجابات المبحوثين:

لتحديد اتجاه الإجابات على كل فقرة من فقرات الاستبيان يتم ذلك بمقارنة متوسط الاستجابة لكل فقرة مع البيانات في الجدول رقم (2) وفقاً للآتي:

(1 - 1.79) يكون اتجاه الإجابة غير موافق بشـدة، (1.8 - 2.59 ) يكون اتجاه الإجابة غير موافق، (2.6 - 3.39) يكون اتجاه الإجابة محايد، (3.4 - 4.19) يكون اتجاه الإجابة موافق، (4.2 - 5) يكون اتجاه الإجابة موافق بشدة.

ولتحديد مستوى كل متغير، تم استخدام اختبار (OneSample T-Test)، فيكون مستوى المتغير مرتفع إذا كانت قيمة الدلالة الإحصائية أقل من (0.05) و قيمة متوسط الاستجابة لإجمالي المحور أكبر من قيمة متوسط القياس (3)، ويكون مستوى المتغير منخفضاً إذا كانت قيمة الدلالة الإحصائية أقل من (0.05) ويكون المستوى متوسطاً إذا كانت قيمة الدلالة الإحصائية أكبر من 0.05.

أولاً: المتغير المستقل ممارسة إدارة الموارد البشرية ( التخطيط - الاختيار والاستقطاب- التدريب): 


\section{Global Proceedings Repository}

American Research Foundation

ISSN 2476-017X
شبكة المؤمرات العربية

http://arab.kmshare.net/

Available online at http://proceedings.sriweb.org

جدول (11) يوضح التوزيعات التكرارية ونتائج التحليل الوصفي لمحور التخطيط

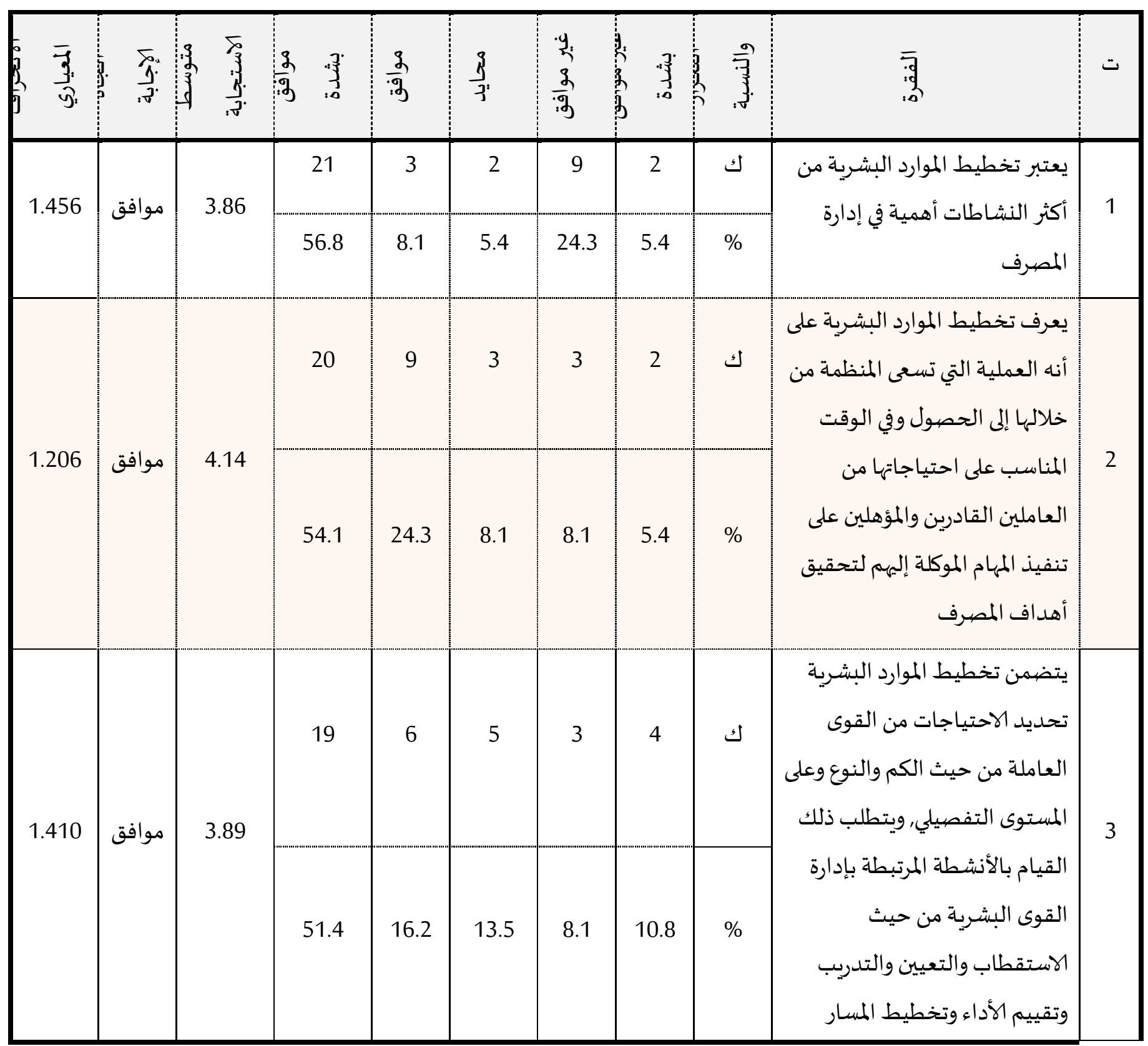




\section{Global Proceedings Repository \\ American Research Foundation}

ISSN 2476-017X
ثبكة المؤمرات العربية

http://arab.kmshare.net/

Available online at http://proceedings.sriweb.org

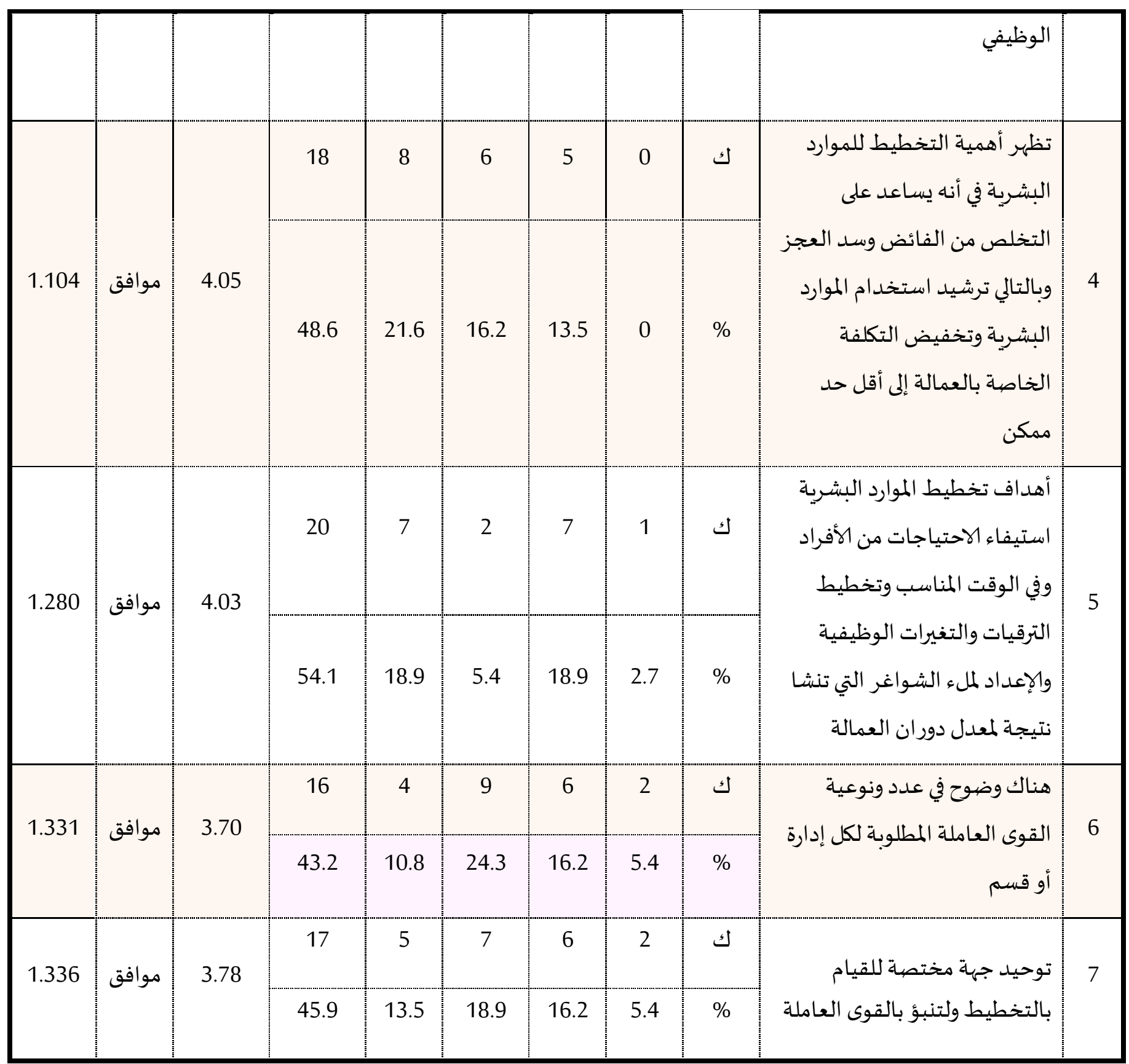

تبين من خلال الجدول(11) أن أفراد العينة متفقون على جميع فقرات المحور:

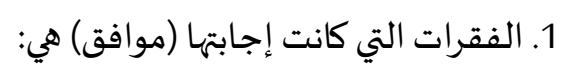

جدول رقم (12) نتائج اختبار (One Sample T- test) لإجمالي محور التخطيط 


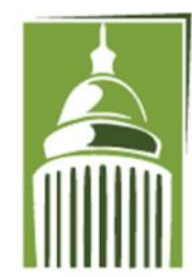

AR F

\section{Global Proceedings Repository}

American Research Foundation

ISSN 2476-017X
شبكة المؤمرات العربية

http://arab.kmshare.net/

Available online at http://proceedings.sriweb.org

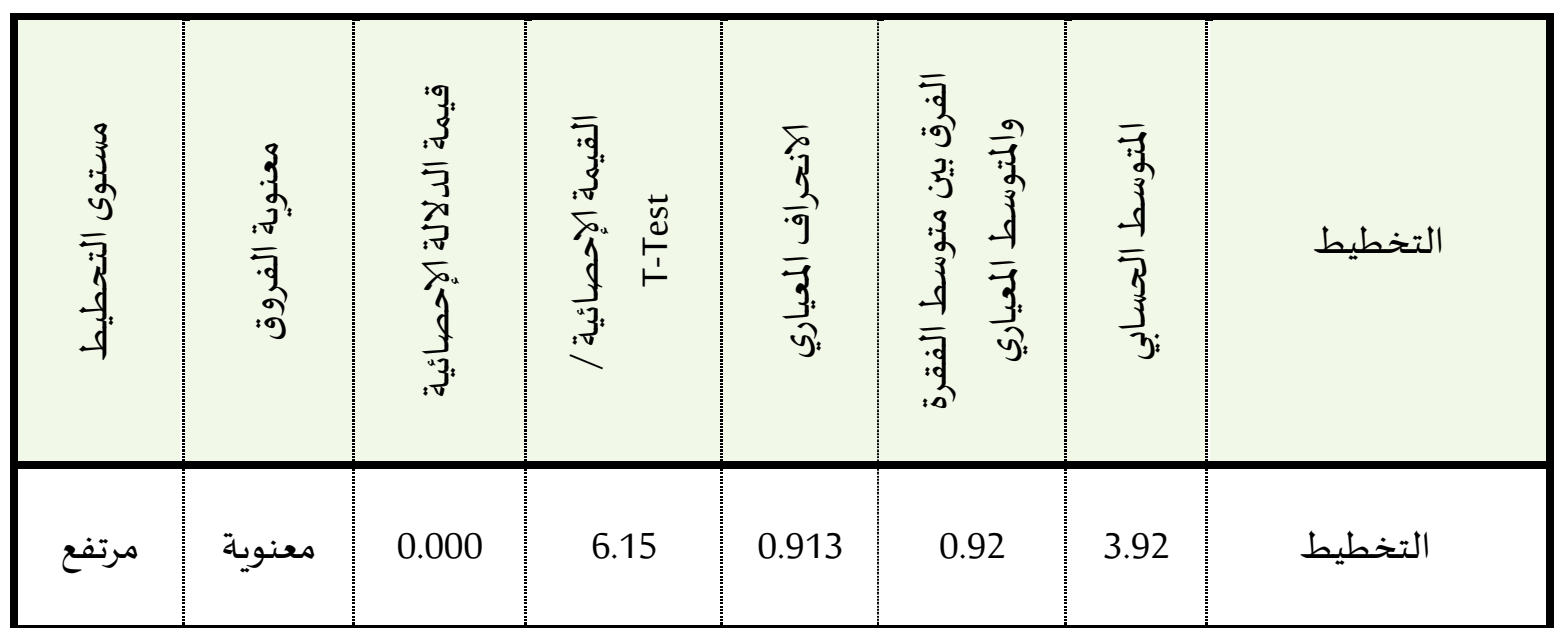

وللتعرف على مستوى التخطيط فإن النتائج في الجدول رقم (12) أظهرت أن متوسط الاستجابة لإجمالي محور التخطيط

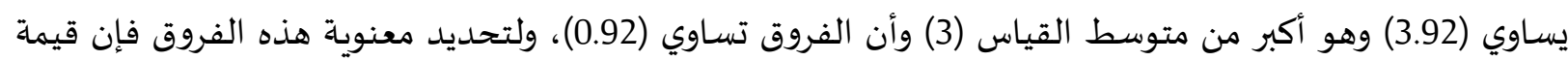
الدلالة الإحصائية للاختبار تساوي صفراً وهي أقل من 0.05 وتشير إلى معنوية الفروق، وهذا يدل على ألى أن مستوى التخطيط كان مرتفعاً.

2

جدول (12) يوضح التوزيعات التكرارية ونتائج التحليل الوصفي لمحور الاختيار والاستقطاب

\begin{tabular}{|c|c|c|c|c|c|c|c|c|c|c|}
\hline $\begin{array}{ll}\frac{5}{9} & \overline{3} \\
\frac{1}{9} & \text { ज: }\end{array}$ & $\frac{5}{10}$ & 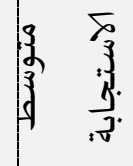 & 多 & $\frac{\xi}{9}$ & $\frac{3}{3}$ & $\begin{array}{l}\frac{y}{5} \\
\frac{j}{2}\end{array}$ & : & 氯高 & 武 & ت \\
\hline \multirow{2}{*}{1.361} & \multirow{2}{*}{ موافق } & \multirow{2}{*}{3.62} & 15 & 6 & 4 & 11 & 1 & ك & \multirow{2}{*}{ تقعملها لجنة التوظيف المعايير } & \multirow{2}{*}{1} \\
\hline & & & 40.5 & 16.2 & 10.8 & 29.7 & 2.7 & $\%$ & & \\
\hline \multirow[t]{2}{*}{1.325} & \multirow[t]{2}{*}{ موافق } & \multirow[t]{2}{*}{3.54} & 13 & 6 & 8 & 8 & 2 & ك & \multirow{2}{*}{ لجنة الإجراء التوظيف } & \multirow[t]{2}{*}{2} \\
\hline & & & 35.1 & 16.2 & 21.6 & 21.6 & 5.4 & $\%$ & & \\
\hline \multirow{2}{*}{1.446} & \multirow{2}{*}{ محايد } & \multirow{2}{*}{3.27} & 11 & 6 & 7 & 8 & 5 & ك & \multirow{2}{*}{ يتم عقد دورات تدريبية } & \multirow{2}{*}{3} \\
\hline & & & 297 & 162 & 189 & 216 & 13.5 & $\%$ & & \\
\hline
\end{tabular}




\section{Global Proceedings Repository}

American Research Foundation

ISSN 2476-017X
ثبكة المؤمرات العربية

http://arab.kmshare.net/

Available online at http://proceedings.sriweb.org

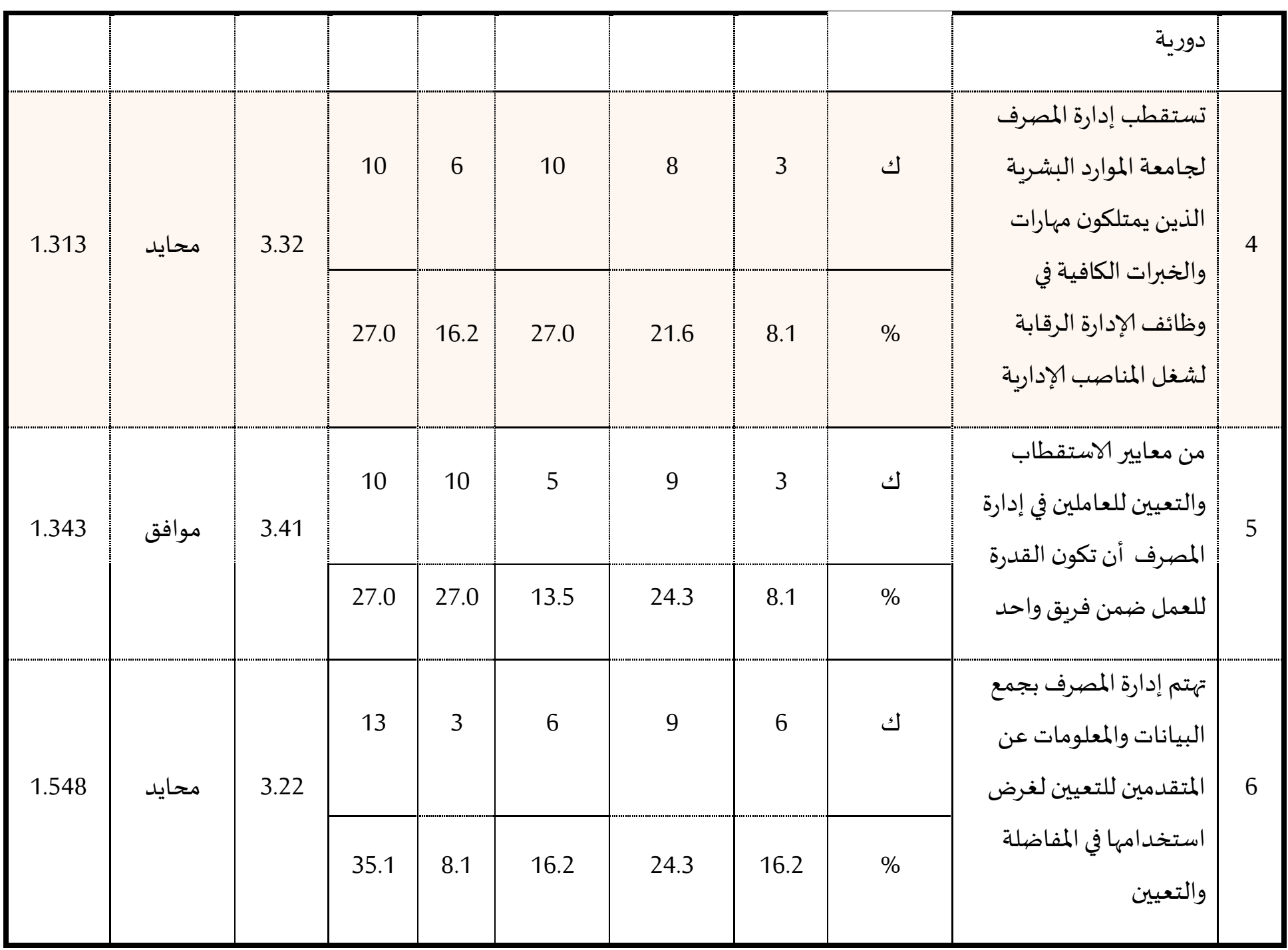

تبين من خلال الجدول (13) الآتي :

1. - الفقرات التي كانت إجابتها (موافق) هي:

أ. تقوم لجنة التوظيف بعملهاوفق المعايير المعتمدة.

ب. لجنة الإجراء التوظيف مؤهلة .

ج. من معايير الاستقطاب والتعيين للعاملين في إدارة الجامعة أن تكون القدرة للعمل ضمن فريق واحد.

2. - الفقرات الي كانت إجابتها (محايد) هي: 


\section{Global Proceedings Repository}

American Research Foundation

ISSN 2476-017X
شبكة المؤمرات العربية

http://arab.kmshare.net/

Available online at http://proceedings.sriweb.org

أ. يتم عقد دورات تدربيية لأعضياء اللجنة بصورة دورية.

ب. تستقطب إدارة الجامعة الموارد البشرية الذين يمتلكون مهارات والخبرات الكافية في وظائف الإدارة الرقابة لشغل المناصب الإدارية .

ج. تهتم إدارة الجامعة بجمع البيانات والمعلومات عن المتقدمين للتعيين لغرض استخدامها في المفاضلة والتعيين. جدول رقم (14) نتائج اختبار (One Sample T- test) لإجمالي محور الاختيار والاستقطاب

\begin{tabular}{|c|c|c|c|c|c|c|c|}
\hline 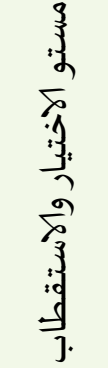 & 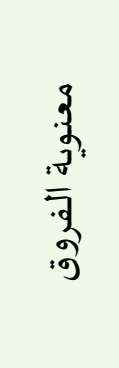 & 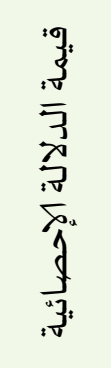 & 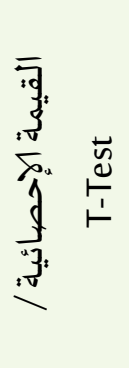 & $\begin{array}{l}\frac{5}{0} \\
\frac{3}{9} \\
\frac{5}{3} \\
\frac{3}{9}\end{array}$ & 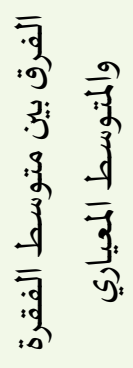 & $\begin{array}{l}\bar{y} \\
3 \\
\overline{3} \\
\overline{3} \\
3\end{array}$ & المجال \\
\hline مرتفع & معنوية & 0.036 & 2.174 & 1.109 & 0.4 & 3.4 & الاختيار والاستقطاب \\
\hline
\end{tabular}

وللتعرف على مستوى الاختيار والاستقطاب فإن النتائج في الجدول رقم (14) أظهرت أن متوسط الاستجابة لإجمالي المحور

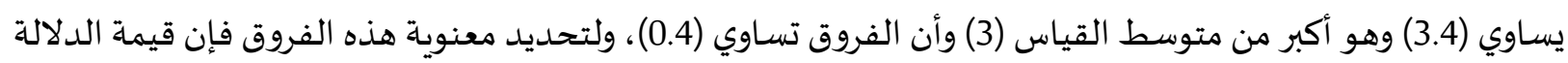
الإحصائية للاختبار تساوي (3.4) وهو اكير من منوسطان وهي أقل من 0.05 وتشير إلى معنوية الفروق، وهذا يدل على أن مستوى الاختيار والاستقطاب كان مرتفعاً. ثالثاً : التدريب جدول (15) يوضح التوزيعات التكرارية ونتائج التحليل الوصفي لمحور التدريب

\begin{tabular}{|c|c|c|c|c|c|c|c|c|c|c|}
\hline $\begin{array}{ll}\frac{6}{3} & 3 \\
\frac{3}{9} & \text { क: }\end{array}$ & $\frac{5}{3}$ & 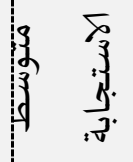 & 责 & $\frac{2}{9}$ & $\frac{3}{3}$ & $\begin{array}{l}\frac{y}{2} \\
\frac{g}{2} \\
\frac{9}{9}\end{array}$ & $\begin{array}{ll}\frac{1}{1} & \\
3 & 3 \\
\frac{3}{3} & 3\end{array}$ & 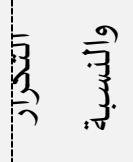 & 武忽 & $ت$ \\
\hline \multirow[t]{2}{*}{1.524} & \multirow{2}{*}{ 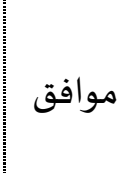 } & \multirow{2}{*}{3.89} & 10 & 3 & 4 & 13 & 7 & ك & \multirow{2}{*}{ للتدوم الإدارة بتقديم الدعم الكاف } & \multirow{2}{*}{1} \\
\hline & & & 27.0 & 8.1 & 10.8 & 35.1 & 18.9 & $\%$ & & \\
\hline 1.417 & محايد & 3.22 & 12 & 3 & 5 & 15 & 2 & ك & يعد البرنامج التدريبي التي التحقت & 2 \\
\hline
\end{tabular}




\section{Global Proceedings Repository}

American Research Foundation

ISSN 2476-017X
شبكة المؤمرات العربية

http://arab.kmshare.net/

Available online at http://proceedings.sriweb.org

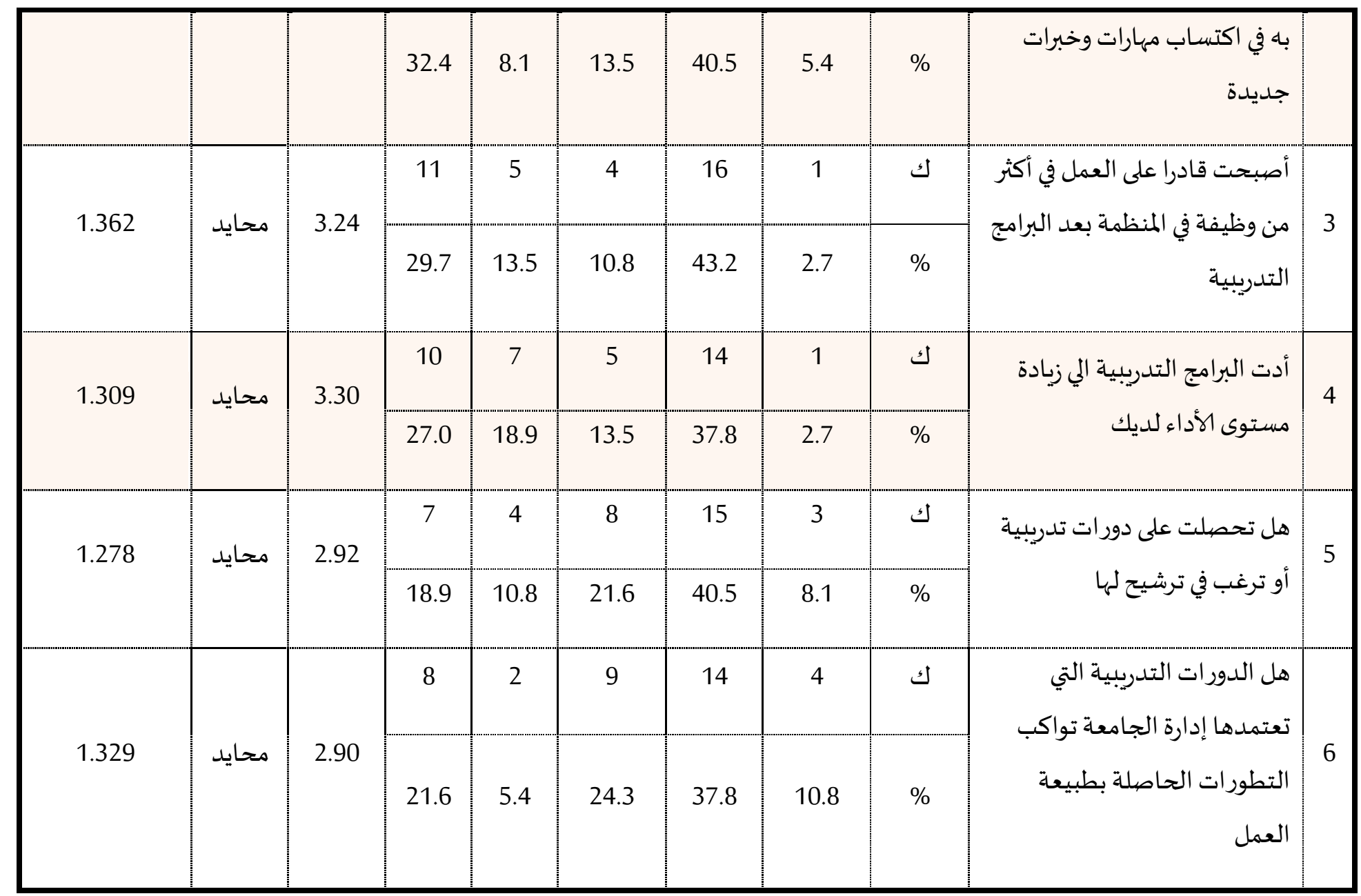

تبين من خلال الجدول (15) أن :

1. - الفقرات التي كانت إجابتها (موافق) هي:

أ. تقوم الإدارة بتقديم الدعم الكاف للتدريب.

2. - الفقرات التي كانت إجابتها (محايد) هي:

أ. يعد البرنامج التدريبي التي التحقت به في اكتساب مهارات وخبرات جديدة.

ب. أصبحت قادرا على العمل في أكثر من وظيفة في المنظمة بعد البرامج التدربية.

ج. أدت البرامج التدربيية الي زيادة مستوى الأداء لديك.

د. هل تحصلت على دورات تدريبية أو ترغب في ترشيح لها. 


\section{Global Proceedings Repository}

American Research Foundation

ISSN 2476-017X

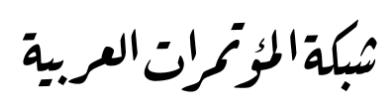

http://arab.kmshare.net/

Available online at http://proceedings.sriweb.org

هـ هل الدورات التدريبية التي تعتمدها إدارة الجامعة تواكب التطورات الحاصلة بطبيعة العمل.

جدول رقم (16) نتائج اختبار (One Sample T- test) لإجمالي محور التدريب

\begin{tabular}{|c|c|c|c|c|c|c|c|}
\hline $\begin{array}{l}3 \\
3 \\
y \\
3 \\
3 \\
3\end{array}$ & 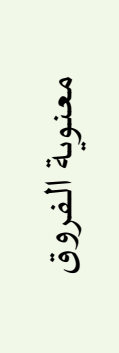 & 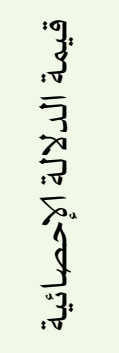 & 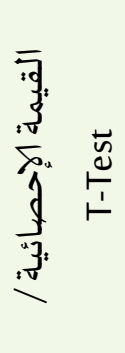 & $\begin{array}{l}\frac{5}{3} \\
\frac{3}{9} \\
\frac{5}{3} \\
\frac{3}{3}\end{array}$ & 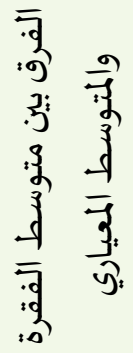 & $\begin{array}{l}\overline{3} \\
3 \\
\frac{1}{3} \\
\overline{3} \\
3 \\
3\end{array}$ & المجال \\
\hline متوسط & معنوية & 0.658 & 0.446 & 1.044 & 0.08 & 3.08 & التدريب \\
\hline
\end{tabular}

وللتعرف على مستوى التدريب فإن النتائج في الجدول رقم (16) أظهرت أن متوسط الاستجابة لإجمالي محور التدريب

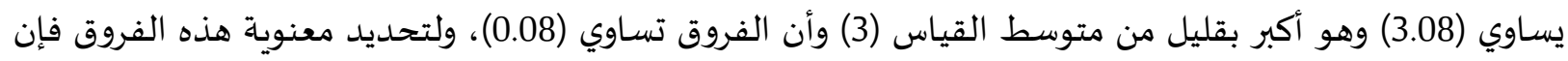

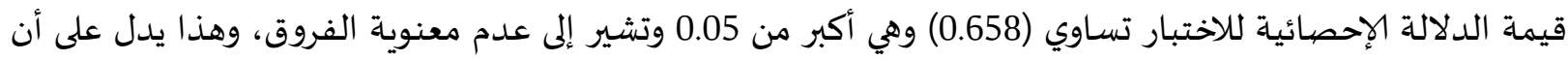
مستوى التدريب كان متوسطاً.

ثانياً: المتغير التابع : التقييم والأداء

جدول (17) يوضح التوزيعات التكرارية ونتائج التحليل الوصفي لمحور التقييم والأداء

\begin{tabular}{|c|c|c|c|c|c|c|c|c|c|c|}
\hline $\begin{array}{ll}\frac{5}{3} & \overline{3} \\
\frac{9}{\sigma} & \bar{y}\end{array}$ & 留 & $\begin{array}{l}5 \\
3 \\
3 \\
3 \\
3 \\
3 \\
3\end{array}$ & 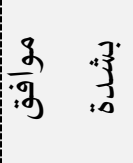 & $\frac{2}{9}$ & $\frac{3}{3}$ & $\begin{array}{l}\frac{y}{2} \\
\frac{\xi}{9} \\
\frac{9}{9}\end{array}$ & 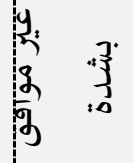 & 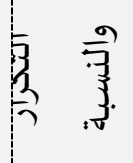 & 求 & ت \\
\hline \multirow{2}{*}{1.092} & \multirow{2}{*}{ 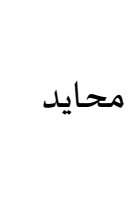 } & \multirow{2}{*}{3.59} & 11 & 6 & 14 & 6 & 0 & ك & \multirow{2}{*}{ يتم العمل داخل الشركة بهيكل } & \multirow{2}{*}{1} \\
\hline & & & 29.7 & 16.2 & 37.8 & 16.2 & 0 & $\%$ & & \\
\hline \multirow{2}{*}{1.187} & \multirow{2}{*}{ 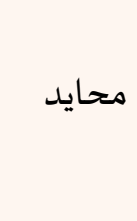 } & \multirow{2}{*}{3.08} & 6 & 8 & 7 & 15 & 1 & ك & \multirow{2}{*}{ بتحصل بحرات ومهارات عالية على فرصين الذين يتمتعون } & \multirow{2}{*}{2} \\
\hline & & & 16.2 & 21.6 & 18.9 & 40.5 & 2.7 & $\%$ & & \\
\hline 1.322 & موافق & 3.41 & 12 & 5 & 7 & 12 & 1 & ك & تعتمد الشركة على الوسـائل & 3 \\
\hline
\end{tabular}




\section{Global Proceedings Repository \\ American Research Foundation}

ISSN 2476-017X
شبكة المؤرمُات العربية

http://arab.kmshare.net/

Available online at $\underline{\mathrm{http}: / / \text { proceedings.sriweb.org }}$

\begin{tabular}{|c|c|c|c|c|c|c|c|c|c|c|}
\hline & & & 32.4 & 13.5 & 18.9 & 32.4 & 2.7 & $\%$ & التقنية الحديثة لانجاز الوظائف & \\
\hline \multirow[t]{2}{*}{1.367} & \multirow[t]{2}{*}{ 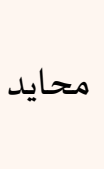 } & \multirow[t]{2}{*}{3.27} & 10 & 8 & 3 & 14 & 2 & ك & \multirow{2}{*}{ تحفيز العاملين أهداف الجامعة يساهم في } & \multirow[t]{2}{*}{4} \\
\hline & & & 27.0 & 21.6 & 8.1 & 37.8 & 5.4 & $\%$ & & \\
\hline \multirow{2}{*}{1.296} & \multirow{2}{*}{ 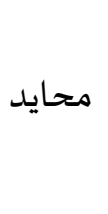 } & \multirow{2}{*}{3.35} & 11 & 4 & 11 & 9 & 2 & ك & \multirow{2}{*}{ 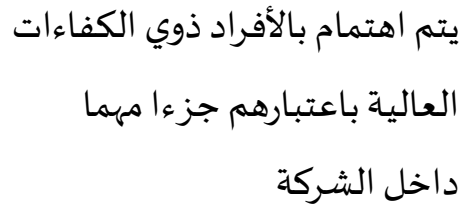 } & \multirow{2}{*}{5} \\
\hline & & & 29.7 & 10.8 & 29.7 & 24.3 & 5.4 & $\%$ & & \\
\hline \multirow{2}{*}{1.457} & \multirow{2}{*}{ 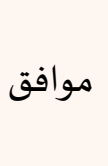 } & \multirow{2}{*}{3.65} & 18 & 2 & 5 & 10 & 2 & ك & \multirow[t]{2}{*}{ يتقيد العاملين بقواعد } & \multirow{2}{*}{6} \\
\hline & & & 48.6 & 5.4 & 13.5 & 27.0 & 5.4 & $\%$ & & \\
\hline \multirow{2}{*}{1.385} & \multirow{2}{*}{ 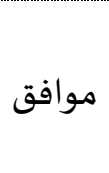 } & \multirow{2}{*}{3.84} & 19 & 4 & 5 & 7 & 2 & ك & \multirow{2}{*}{ يشعر العاملون بالولاء للمنظمة } & \multirow{2}{*}{7} \\
\hline & & & 51.4 & 10.8 & 13.5 & 18.9 & 5.4 & $\%$ & & \\
\hline \multirow[t]{2}{*}{1.236} & \multirow[t]{2}{*}{ 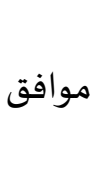 } & \multirow[t]{2}{*}{4.02} & 20 & 5 & 6 & 5 & 1 & ك & \multirow{2}{*}{ العمل بالمنظمة تعاون بين العاملين لانجاز } & \multirow[t]{2}{*}{8} \\
\hline & & & 54.1 & 13.5 & 16.2 & 13.5 & 2.7 & $\%$ & & \\
\hline \multirow{2}{*}{1.228} & \multirow{2}{*}{ موافق } & \multirow{2}{*}{3.86} & 16 & 8 & 6 & 6 & 1 & ك & \multirow{2}{*}{ لدى العاملين القدرة على الإبداع } & \multirow{2}{*}{9} \\
\hline & & & 43.2 & 21.6 & 16.2 & 16.2 & 2.7 & $\%$ & & \\
\hline \multirow{2}{*}{1.384} & \multirow{2}{*}{ موافق } & \multirow{2}{*}{3.59} & 14 & 6 & 9 & 4 & 4 & ك & \multirow{2}{*}{ تعتبر الجامعة مكان جيدة } & \multirow{2}{*}{10} \\
\hline & & & 37.8 & 16.2 & 24.3 & 10.8 & 10.8 & $\%$ & & \\
\hline
\end{tabular}

تبين من خلال الجدول (17) أن :

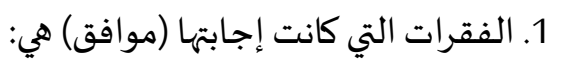

أ. تعتمد الشركة على الوسائل التقنية الحديثة لانجاز الوظائف. 


\section{Global Proceedings Repository}

American Research Foundation

\section{ISSN 2476-017X}

شبكة المؤمرات العربية

http://arab.kmshare.net/

Available online at http://proceedings.sriweb.org

$$
\text { ب. يتقيد العاملين بقواعد وإجراءات العاملين. }
$$

د. يوجد تعاون بين العاملين لانجاز العمل بالمنظمة. .

$$
\text { هـ لدى العاملين القدرة على الإبداع والتطوير . }
$$

و. تعتبر الجامعة مكان جيدة ومناسباً للعمل يساعد على الأداء الوظيفي .

$$
\text { 2. - الفقرات التي كانت إجابتها (محايد) هي: }
$$

أ. يتم العمل داخل الشركة بهيكل التنظيمي واضح يحدد مسؤوليات وصلاحيات بجميع الموظفين . ب. يحصل الموظفين الذين يتمتعون بقدرات ومهارات عالية على فرص بتطوير أنفسهم .

\begin{tabular}{|c|c|c|c|c|c|c|c|}
\hline 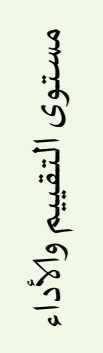 & 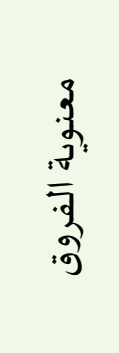 & 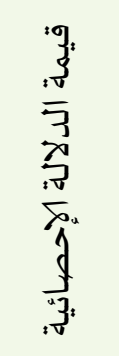 & 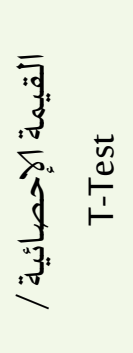 & $\begin{array}{l}\frac{5}{0} \\
\frac{2}{9} \\
\frac{9}{3} \\
\frac{3}{3}\end{array}$ & 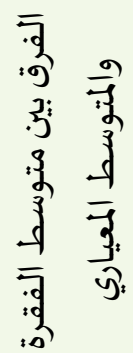 & $\begin{array}{l}\overline{7} \\
\frac{7}{3} \\
\frac{3}{3} \\
3\end{array}$ & المجال \\
\hline مرتفع & معنوية & 0.001 & 3.526 & 0.979 & 0.57 & 3.57 & التقييم والأداء \\
\hline
\end{tabular}
ج. وضوح أهداف الجامعة يساهم في تحفيز العاملين. د. يتم اهتمام بالأفراد ذوي الكفاءات العالية باعتبارهم جزءا مهما داخل الشركة جدول رقم (18) نتائج اختبار (One Sample T- test) لإجمالي محور التقييم والأداء

وللتعرف على مستوى التقييم والأداء فإن النتائج في الجدول رقم (18) أظهرت أن متوسط الاستجابة لإجمالي محور التقييم والأداء يساوي (3.57) وهو أكبر من متوسط القياس (3) وأن الفروق تساوي (0.57)، ولتحديد معنوية هذه الفروق فإن

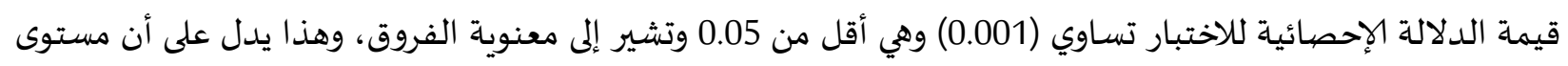
التقييم والأداء كان مرتفعاً. 


\section{Global Proceedings Repository}

American Research Foundation

ISSN 2476-017X

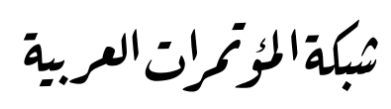

http://arab.kmshare.net/

Available online at http://proceedings.sriweb.org

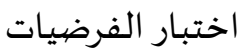

لاختبار صحة فرضيات الدراسة تم استخدام ارتباط بيرسون لاختبار جوهرية العلاقة بين ممارسة إدارة الموارد البشرية والأداء، فتكون العلاقة طردية إذا كانت قيمة معامل الارتباط موجبة وتكون عكسية إذا كانت قيمة معامل الارتباط سالبة، وتكون العلاقة معنوية (ذات دلالة إحصائية) إذا كانت قيمة الدلالة الإحصائية أقل من 0.05، وتكون غير معنوية اذا كانت قيمة الدلالة الإحصيائية أكبر من 0.05.

ولتحديد أثر ممارسة إدارة الموارد البشرية على الأداء، سيتم استخدام تباين الانحدار لبيان نسبة أثر المتغير المستقل على المتغير التابع عن طريق معامل التحديد.

الفرضية الرئيسية: يوجد أثر لممارسة إدارة الموارد البشرية (التخطيط، الاختيار والاستقطاب والتدربب) على أداء المنظمة. ويتفرع من هذه الفرضية الفرضيات الفرعية التالية :الفرضية الفرعية الأولي : يوجد أثر معنوي ذو دلالة إحصائية للتخطيط على الأداء في المنظمة قيد الدراسـة. جدول (19) نتائج تباين الانحدار لتحديد أثر التخطيط على أداء المنظمة

\begin{tabular}{|c|c|c|c|c|c|c|}
\hline \multicolumn{2}{|c|}{ معاملات الانحدار } & \multirow{2}{*}{ التحديد (R2) } & \multirow{2}{*}{ الارتباط معامل } & \multirow{2}{*}{ قيمة الدلالة } & \multirow{2}{*}{ قلمحسيمة F } & \multirow{2}{*}{ الحربة } \\
\hline التخطيط & الثابت & & & & & \\
\hline 0.397 & 2.01 & 0.137 & 0.37 & 0.024 & 5.555 & 36 \\
\hline
\end{tabular}

أظهرت النتائج في الجدول رقم (19) وجود علاقة إيجابية معنوية بين التخطيط وأداء المنظمة، حيث كانت قيمة معامل الارتباط (0.37) وتشير إلى إيجابية العلاقة بين المتغيرين ، أي أن التخطيط يرفع من مستوى أداء المنظمة. ولتحديد أثر التخطيط على الأداء، فإن تم قيمة F تساوي (5.555) وهي قيمة مرتفعة وكانت قيمة الدلالة الإحصائية (0.024) وهي أقل من 0.05 ، وهذا يدل على وجود أثر ذو دلالة إحصائية للتخطيط على الأداء، وكانت قيمة معامل التحديد (0.137) وهي تشير إلى أن ما نسبته (13.7\%) من التغيرات في أداء المنظمة يعود إلى التخطيط ما لم يؤثر مؤثر أخر. ويمكن تقدير معالم نموذج الانحدار حسب معادلة الانحدار بالشكل التالي:

$Y=2.91+0.397 * X 1+\varepsilon$ 


\section{Global Proceedings Repository}

American Research Foundation

\section{ISSN 2476-017X}

Available online at http://proceedings.sriweb.org
ثبكةالمزّمراتيالربية

http://arab.kmshare.net/

AR F

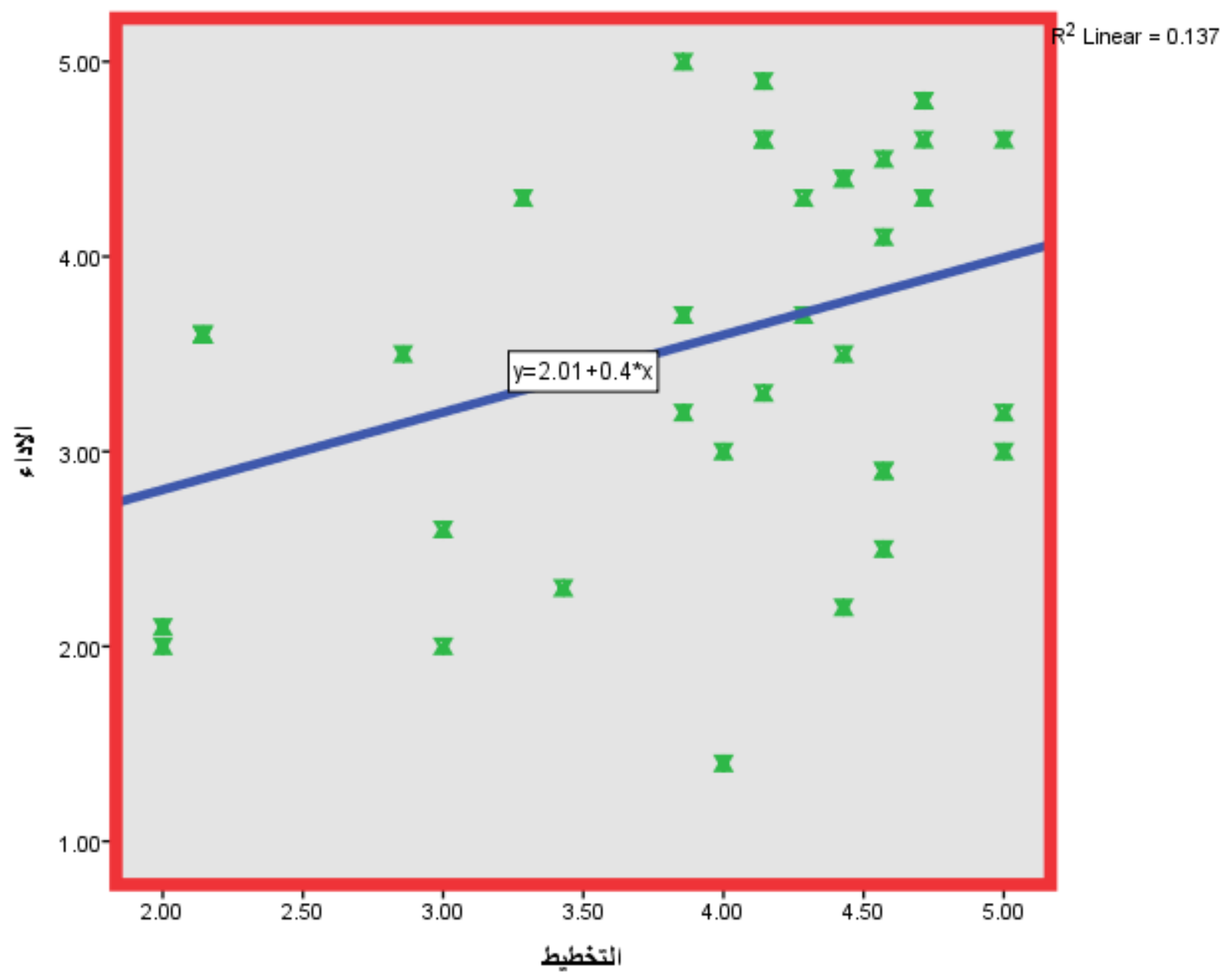

شكل (6) العلاقة بين التخطيط والأداء

الفرضية الفرعية الثانية : يوجد أثر معنوي ذو دلالة إحصائية للاختيار والاستقطاب على الأداء في المنظمة قيد الدراسـة. جدول (20) نتائج تباين الانحدار لتحديد أثر الاختيار والاستقطاب على أداء المنظمة 


\section{Global Proceedings Repository}

American Research Foundation

\section{ISSN 2476-017X}

شبكة المؤرمُات العربية

http://arab.kmshare.net/

Available online at http://proceedings.sriweb.org

\begin{tabular}{|c|c|c|c|c|c|c|}
\hline \multicolumn{2}{|c|}{ معاملات الانحدار } & \multirow{2}{*}{ التحديد (R2) معامل } & \multirow{2}{*}{ الارتباط معامل } & \multirow{2}{*}{ قالدلالة } & \multirow{2}{*}{ قلمحسمة F } & \multirow{2}{*}{ الحرجات } \\
\hline الاختيار والاستقطاب & الثابت & & & & & \\
\hline 0.652 & 1.354 & 0.545 & 0.738 & 0.000 & 41.967 & 36 \\
\hline
\end{tabular}

أظهرت النتائج في الجدول رقم (20) وجود علاقة إيجابية معنوية بين الاختيار والاستقطاب وأداء المنظمة، حيث كانت قيمة معامل الارتباط (0.738) وتشير إلى إيجابية العلاقة بين المتغيرين ، أي أن الاختيار والاستقطاب يرفع من مستوى أداء المنظمة.

ولتحديد أثر الاختيار والاستقطاب على الأداء، فإن تم قيمة F تساوي (41.967) وهي قيمة مرتفعة وكانت قيمة الدلالة الإحصائية صفراً وهي أقل من 0.05 ، وهذا يدل على وجود أثر ذو دلالة إحصائية للاختيار والاستقطاب على الأداء، وكانت قيمة معامل التحديد (0.545) وهي تشير إلى أن ما نسبته (54.5\%) من التغيرات في أداء المنظمة يعود إلى الاختيار والاستقطاب ما لم يؤثر مؤثر أخر. ويمكن تقدير معالم نموذج الانحدار حسب معادلة الانحدار بالشكل التالي: $Y=1.354+0.652 * X 2+\varepsilon$ 
Global Proceedings Repository

American Research Foundation

\section{ISSN 2476-017X}

ثبكةالمزّمراتيالربية

http://arab.kmshare.net/

Available online at http://proceedings.sriweb.org

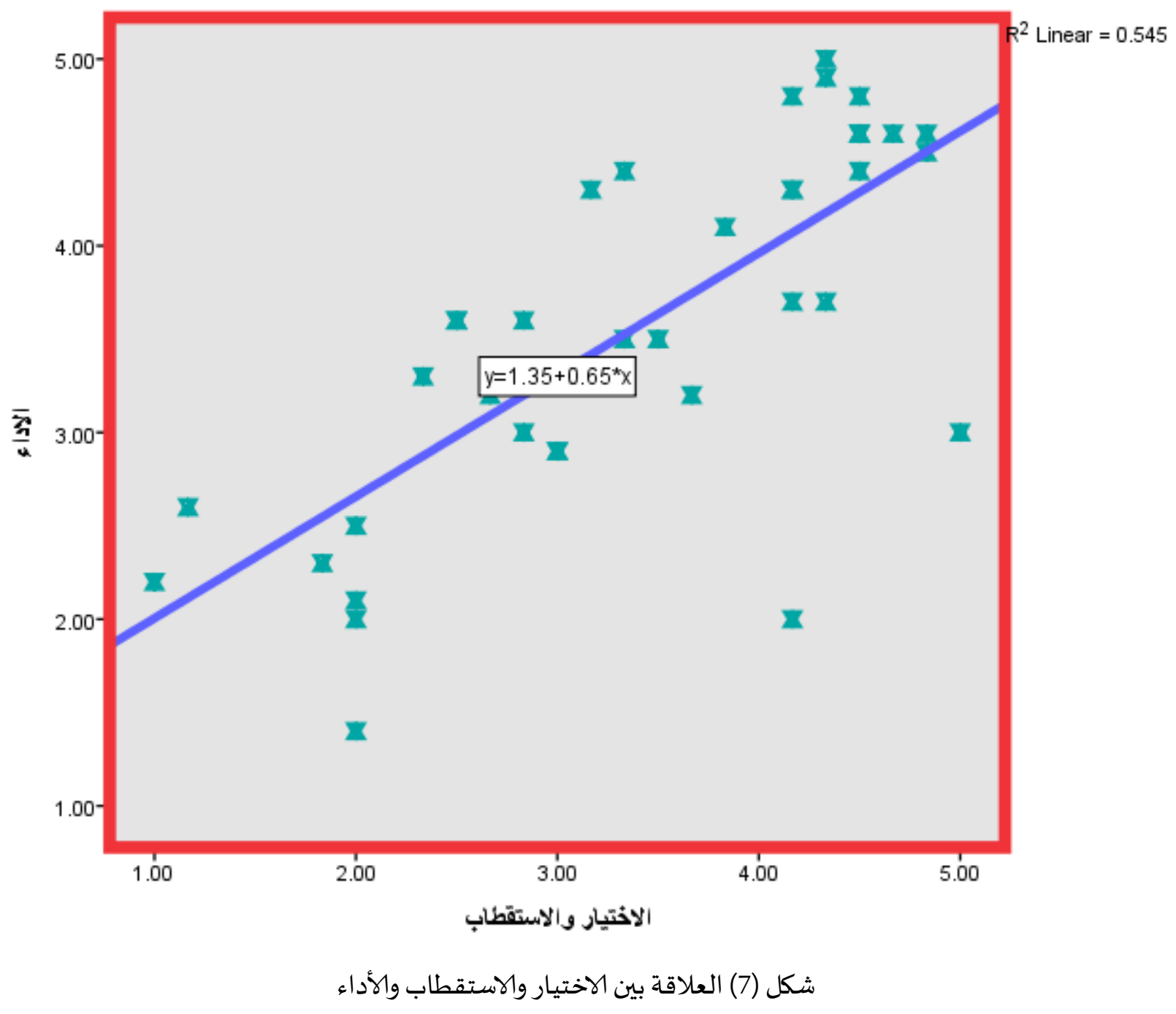




\section{Global Proceedings Repository}

American Research Foundation

\section{ISSN 2476-017X}

شبكة المؤمرات العربية

http://arab.kmshare.net/

Available online at http://proceedings.sriweb.org

الفرضية الفرعية الثالثة : يوجد أثر معنوي ذو دلالة إحصائية التدريب على الأداء في المنظمة قيد الدراسة.

جدول (21) نتائج تباين الانحدار لتحديد أثر التدريب على أداء المنظمة

\begin{tabular}{|c|c|c|c|c|c|c|}
\hline \multicolumn{2}{|c|}{ معاملات الانحدار } & \multirow{2}{*}{ التحديد (R2) } & \multirow{2}{*}{ الارتباط } & \multirow{2}{*}{ قلدملة } & \multirow{2}{*}{ قلمحسمة F } & \multirow{2}{*}{ الحرجات } \\
\hline التدريب & الثابت & & & & & \\
\hline 0.699 & 1.417 & 0.543 & 0.745 & 0.000 & 43.777 & 36 \\
\hline
\end{tabular}

أظهرت النتائج في الجدول رقم (21) وجود علاقة إيجابية معنوية بين التدريب وأداء المنظمة، حيث كانت قيمة معامل الارتباط (0.745) وتشير إلى إيجابية العلاقة بين المتغيرين ، أي أن التدريب يرفع من مستوى أداء المنظمة. ولتحديد أثر التدريب على الأداء، فإن تم قيمة F تساوي (43.777) وهي قيمة مرتفعة وكانت قيمة الدلالة الإحصائية صفراً وهي أقل من 0.05 ، وهذا يدل على وجود أثر ذو دلالة إحصائية للتدريب على الأداء، وكانت قيمة معامل التحديد (0.543) وهي تشير إلى أن ما نسبته (54.3\%) من التغيرات في أداء المنظمة يعود إلى التدريب ما لم يؤثر مؤثر أخر. ويمكن تقدير معالم نموذج الانحدار حسب معادلة الانحدار بالشكل التالي:

$Y=1.417+0.699 * X 3+\varepsilon$

الأداء، X3 التدريب ،عالخطأ العشـوائي 
Global Proceedings Repository

American Research Foundation

\section{ISSN 2476-017X}

ثبكةالمزّمراتيالربية

http://arab.kmshare.net/

Available online at http://proceedings.sriweb.org

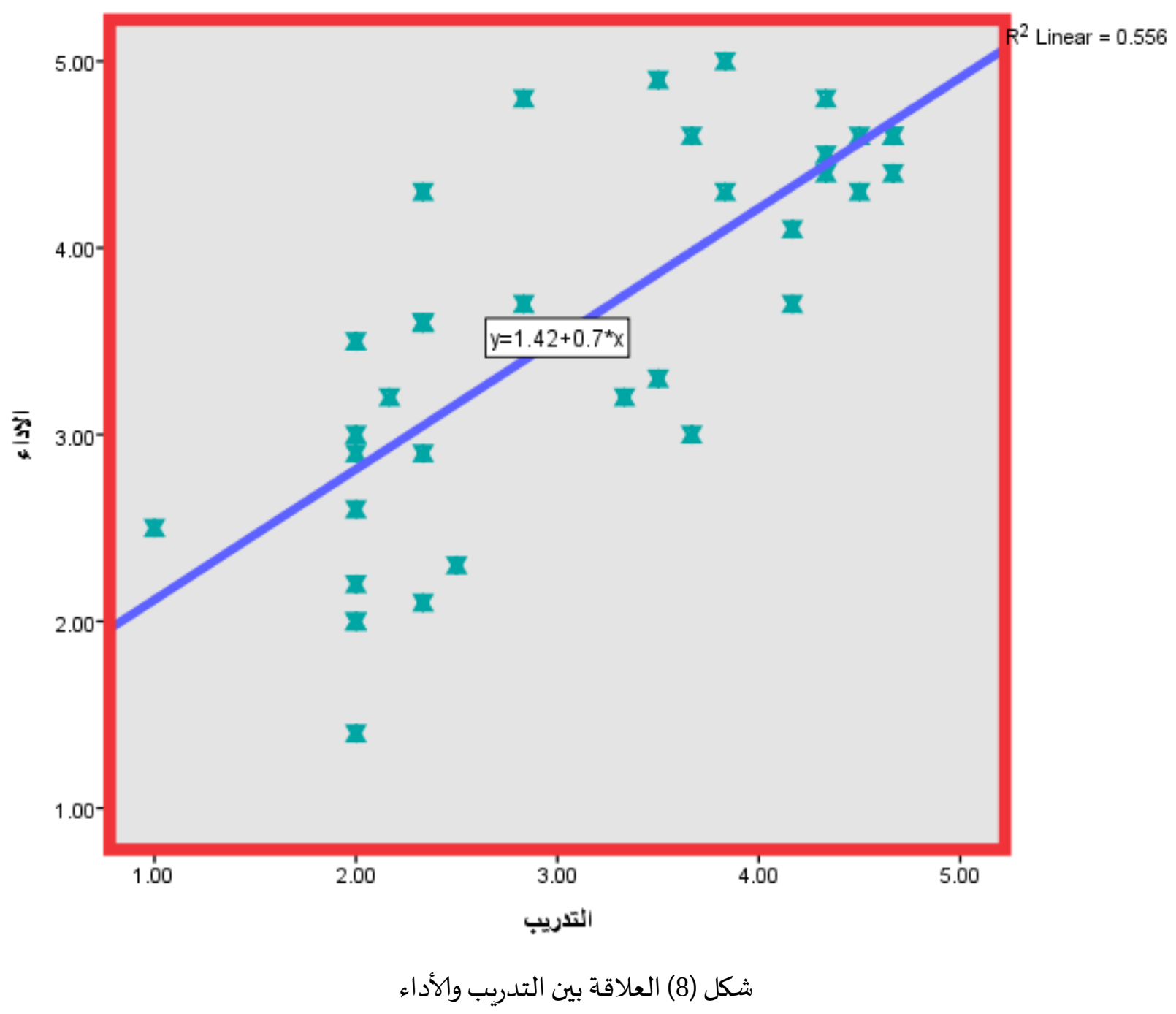




\section{Global Proceedings Repository}

American Research Foundation

ISSN 2476-017X
ثبكة المؤمرات العربية

http://arab.kmshare.net/

Available online at http://proceedings.sriweb.org

الفرضية الرئيسية: يوجد أثر القيادة الإدارية (التوجيا ، الاتصالات والتحفيز) على الدافعية في المنظمة قيد الدراسة. ويتفرع من هذه الفرضية الفرضيات الفرعية التالية.

جدول (22) نتائج تباين الانحدار لتحديد أثر ممارسة إدارة الموارد البشرية على أداء المنظمة

\begin{tabular}{|c|c|c|c|c|c|c|c|c|}
\hline \multicolumn{4}{|c|}{ معاملات الانحدار } & \multirow{2}{*}{$\begin{array}{c}\text { التحديد } \\
\text { (R2) }\end{array}$} & \multirow{2}{*}{ الاتباط معامل } & \multirow{2}{*}{ قيمة } & \multirow{2}{*}{ قلميمة Fسية } & \multirow{2}{*}{ الحرجات } \\
\hline التدريب & والاختيار & التخطيط & الثابت & & & & & \\
\hline 0.439 & 0.398 & $0.049-$ & 1.059 & 0.665 & 0.815 & 0.000 & 21.83 & 36 \\
\hline
\end{tabular}

بينت النتائج في الجدول رقم (22) وجود علاقة إيجابية معنوية بين ممارسة إدارة الموارد البشرية وأداء المنظمة، حيث كانت قيمة معامل الرتباط (0.815) وتشير إلى إيجابية العلاقة بين المتغيرين ، أي أن ممارسة إدارة الموارد البشرية يرفع من أداء

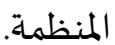

ولتحديد أثر ممارسة إدارة الموارد البشرية على أداء المنظمة ، فإن تم قيمة F تساوي (21.83) وهي قيمة مرتفعة وكانت قيمة الدلالة الإحصائية صفراً وهي أقل من 0.05 ، وهذا يدل على وجود أثر ذو دلالة إحصائية ممارسة إدارة الموارد البشرية على أداء المنظمة، وكانت قيمة معامل التحديد (0.665) وهي تشير إلى أن ما نسبته (66.5\%) من التغيرات في أداء المنظمة يعود إلى ممارسة إدارة الموارد البشرية ما لم يؤثر مؤثر أخر. ويمكن تقدير معالم نموذج الانحدار حسب معادلة الانحدار بالشكل التالي: $Y=1.059-0.049 * X 1+0.398 * X 2+0.439 * X 3+\varepsilon$

ممارسة إدارة الموارد البشرية ، X1 التخطيط، X2 الاختيار والاستقطاب، X3 التدريب ،ع الخطأ العشوائي. 


\section{Global Proceedings Repository}

American Research Foundation

\section{ISSN 2476-017X}

Available online at http://proceedings.sriweb.org
شبكة المؤمرات العربية

http://arab.kmshare.net/

AR F

بناء على هذه الدراسة فأنه تم استخلاص النتائج التالية

5. وجود أثر معنوي ذو دلالة إحصائية للتخطيط على أداء المصارف، وبلفت نسبة الأثر (13.7\%) ما لم يؤثر مؤثر آخر 6. وجود أثر معنوي ذو دلالة إحصائية للاختيار والاستقطاب على أداء المصارف، وبلفت نسبة الأثر (54.5\%) ما لمألم

$$
\text { يؤثر مؤثر آخر }
$$

7. وجود أثر معنوي ذو دلالة إحصائية للتدريب على أداء المصارف ، وبلغت نسبة الأثر (54.3\%) ما لم يؤثر مؤثر آخر.

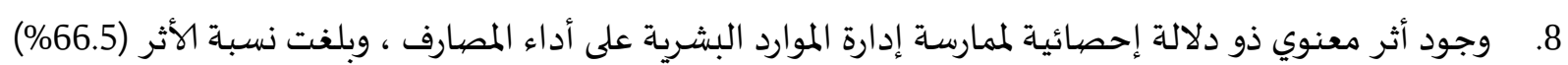

ما لم يؤثر مؤثر آخر.

5. أظهرت الدراسة أن مستوى التخطيط كان مرتفعاً، حيث بلغت قيمة متوسط احتر الاستجابة (3.92) وفق مقياس

$$
\text { التدرج الخماسي. }
$$

6. بينت الدراسة أن مستوى الاختيار والاستقطاب كان مرتفعاً، حيث بلغت قيمة متوسط الاستجابة (3.4) وفق

$$
\text { مقياس التدرج الخماسي. }
$$

7. أوضحت الدراسة أن مستوى التدريب كان متوسطاً ، حيث بلغت قيمة متوسط الاستجابة (3.08) وفق مقياس

$$
\text { التدرج الخماسي. }
$$

8. أظهرت الدراسة أن مستوى الأداء كان مرتفعاً ، حيث بلغت قيمة متوسط الاستجابة (3.57) وفق مقياس التدرج

$$
\text { الخماسي. }
$$

ثانياً : التوصيات 


\section{Global Proceedings Repository \\ American Research Foundation}

\section{ISSN 2476-017X}

شبكة المور تمرات العر.ية

http://arab.kmshare.net/

Available online at http://proceedings.sriweb.org

$$
\text { من خلال نتائج تحليل الدراسة الميدانية فإن الدراسـة توصي بالآتي: }
$$

1- محاولة إقامة الدورات التدرببية بصورة مستمرة وذلك من اجل تطوير عامليها .

2- ضرورة استقطاب إدارة المصارف للموارد البشرية للذين يمتلكون مهارات والخبرات الكافية في وظائف الإدارة

$$
\text { الرقابة لشغل المناصب الإدارية. }
$$

3- ضرورة اهتمام إدارة المصارف بجمع البيانات والمعلومات عن المتقدمين للتعيين لغرض استخدامها في المفاضلة

$$
\text { والتعيين. }
$$

4- ضرورة العمل داخل المصارف بهيكل التنظيمي واضح يحدد مسؤوليات وصلاحيات بجميع الموظفين.

5- ضرورة منح الموظفين الذين يتمتعون بقدرات ومهارات عالية على فرص من أجل تطوير أنفسهم .

6- ضرورة الاهتمام بالأفراد ذوي الكفاءات العالية باعتبارهم جزء اء مهما داخل المصارف.

7- إتاحة الفرصة للعاملين للترقية والانتقال من مكان لأخر.

8- ضرورة بناء العلاقات الجيدة والوطيدة بين الرؤساء والمرؤوسين.

9- ضرورة أن يتضمن تخطيط الموارد البشرية تحديد الاحتياجات من القوى العاملة من حيث الكم والنوع وعلى

المستوى التفصيلي وتقييم الأداء وتخطيط المسار الوظيفي.

العمل على توحيد جهة مختصة للقيام بالتخطيط ولتنبؤ بالقوى العاملة 


\section{Global Proceedings Repository}

American Research Foundation

\section{ISSN 2476-017X}

شبكة المؤمرات العربية

http://arab.kmshare.net/

Available online at http://proceedings.sriweb.org

$$
\text { قائمة المراجع }
$$

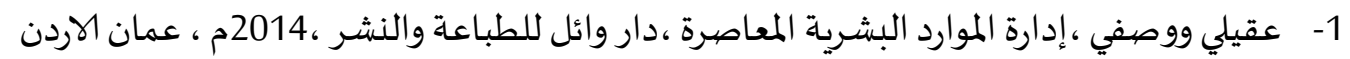

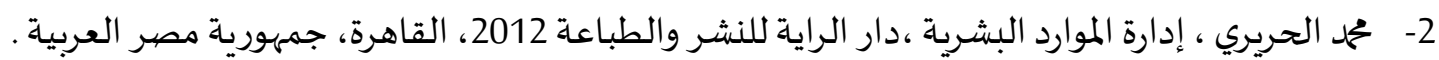

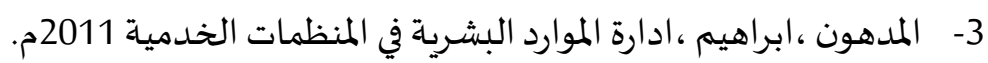

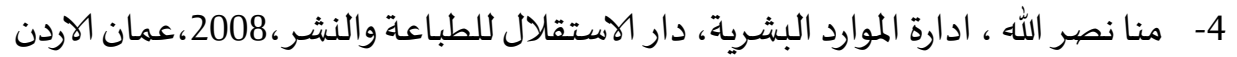

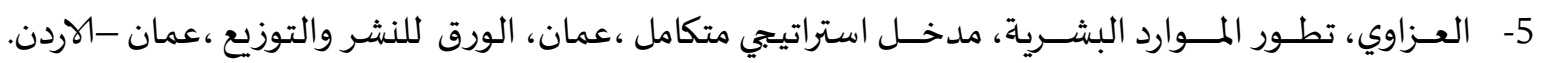

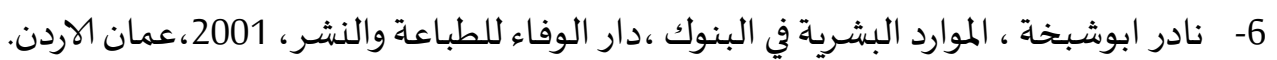

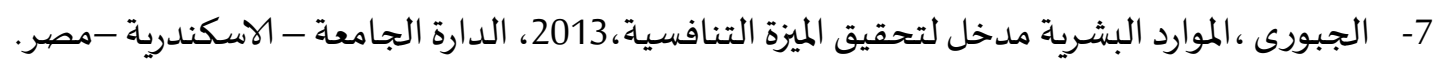

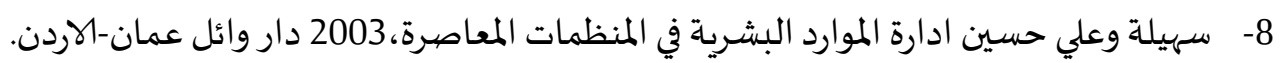

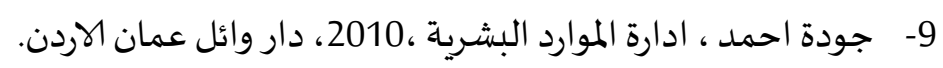
10- الهواري ، الاصول والهس العلمية للقرن الحادى والعشرون ،2002، مكتبة عين شمس ، القاهرة-مصر. 


\section{Global Proceedings Repository}

American Research Foundation

\section{ISSN 2476-017X}

ثبكة المؤتمات العربية

http://arab.kmshare.net/

AR F

Available online at http://proceedings.sriweb.org

1- ابو عائشة طارق (التخطيط الاستراتيجي واثره على الاداء بالشركة الاشتراكية للمواني، طرابلس -ليبيا 2011م).

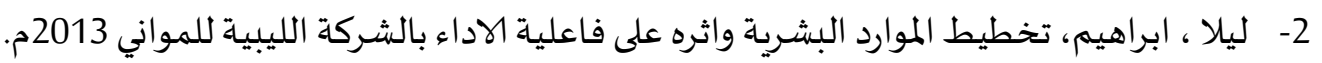

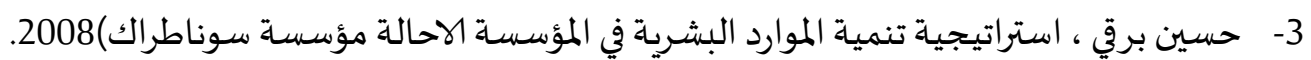

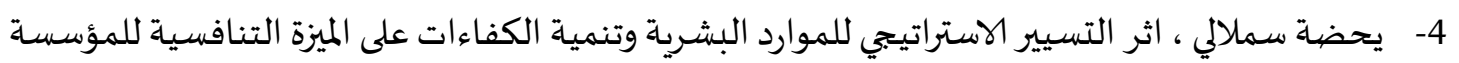
الاقتصادية مدخل الجودة والمعرفة 2004م. 